\title{
Reviewing and theorizing the unintended consequences of performance management systems
}

\author{
Monica Franco-Santos 1 \\ Cranfield University \\ School of Management \\ Cranfield, Bedfordshire \\ MK43 0AL \\ Tel. +44 (0) 1234751122 \\ monica.franco@cranfield.ac.uk
}

\author{
David Otley \\ Lancaster University Management School \\ Department of Accounting and Finance \\ Lancaster LA1 4 YX \\ Tel: +44 (0)1524 593636 \\ d.otley@lancaster.ac.uk
}

${ }^{1}$ Corresponding author. 


\title{
Reviewing and theorizing the unintended consequences of performance management systems
}

\begin{abstract}
Different design choices in the controls used to manage performance often lead to a range of unintended consequences, which have profound effects on individuals and organizations. This paper presents a mixed review (both systematic and eclectic) of the literature on the unintended consequences of performance management systems and develops a typology to explain how and why they occur. It finds that the most salient unintended consequences of directive performance management systems are gaming, information manipulation, selective attention, illusion of control and relationships transformation. It argues that these consequences exist due to limiting factors such as ignorance, error, short-term concerns, fundamental values, self-fulfilling forecasts and changes in social relationships. The emerging typology-based theory suggests that the choice of control mechanisms is based on two key assumptions concerning goal-alignment and goal uncertainty that relate back to ideas in agency theory and stewardship theory. It concludes that, in the design of performance management systems, the more the 'assumed' reality about the state of goal-alignment and goal-uncertainty diverges from the 'real' state of affairs, the more the resultant system is likely to create perverse unintended consequences, leading to poor organisational outcomes.
\end{abstract}

Keywords: Performance management, organizational control, management control, unintended consequences, agency theory, stewardship theory. 


\section{Introduction}

Considerable research has been focused on explaining the extent to which performance management systems (PMSs), involving performance planning, measures, targets, incentives and other means of control, deliver their intended consequences (Franco-Santos et al., 2012; Melnyk et al., 2014; Smith and Bititci, 2017). For example, researchers have studied the effects PMSs have on phenomena such as strategic alignment (Ahn, 2001; Dossi and Patelli, 2010; McAdam and Bailie, 2002), communication (Godener and Eric, 2004), corporate control (Cruz et al., 2011) or accounting performance (Crabtree and DeBusk, 2008; Davis and Albright, 2004; Ittner et al., 2003). These are some of the expected results most leaders have in mind when promoting performance management in their organizations (Ferreira and Otley, 2009). Less attention, however, has been given to the unintended consequences of PMSs (Franco-Santos et al., 2012). A few studies (Bevan and Hood, 2006; Smith, 1995a) have identified common negative side effects (e.g., measure fixation, myopia, gaming or manipulation of data). Yet, whilst we know the general existence of unexpected results, we still know little about how or why they occur. The aim of this paper is to address this gap in our knowledge.

Research in this area is crucial as the unintended consequences of performance management may often have a perverse impact on organizations. For example, a public enquiry into the failings of a UK Hospital Trust (Francis, 2013) found that the overreliance of senior staff on the hospital's PMS led to an organizational culture focused on doing the system's "business" (e.g., hitting performance targets), resulting in patient neglect and high mortality rates. The enquiry emphasized that well-intended decisions associated with the process of managing performance produced consequences that were largely unintended (Francis, 2013). Paradoxically, a system aimed at facilitating the delivery of high-quality patient care and healthy lives, ended up creating the opposite results. Sadly, this event is not a 
rare occurrence, and similar perverse outcomes generated by the use of performance management mechanisms can be found in the literature (Dahler-Larsen, 2014; Lindsay et al., 2014; Parkinson, 2012).

Sociologists have long fostered research on the unintended (Mica et al., 2011). They argue that unintended consequences are actually the norm rather than the exception; and that their existence requires theorising so these consequences can be curtailed (Elias, 1997; Merton, 1936). It follows from these ideas that, if PMSs invariably generate unintended consequences, it is vital for research in this area to go beyond their mere acknowledgement and description. To advance our knowledge, we need a theoretical understanding of the relationship between PMSs and their unintended consequences. This understanding will help us to better assess their effectiveness and minimise their dysfunctional side effects. With that in mind, the objective of this paper is to develop an organizational theory of the unintended consequences of PMSs.

Theory development involves a number of tools and mental processes, some of which are difficult to describe and validate (Bourgeois, 1979; Cornelissen, 2017; Delbridge and Fiss, 2013; Doty and Glick, 1994; Shepherd and Suddaby, 2017; Snow and Ketchen David J., 2014; Weick, 1989). Most scholars agree that a comprehensive review of relevant literature is at the core of any theory construction process (e.g., Bourgeois, 1979). An immersion in the literature can uncover tensions, paradoxes, and numerous puzzles that can lead to compelling explanations (Shepherd and Suddaby, 2017). Thus, following the advice of theory building scholars, our research thoroughly examines the literatures on both performance management and the sociology of the unintended with the purpose of uncovering and explaining, through a typology, the relationship between PMSs and their unintended consequences.

Drawing on the insights extracted from the literature coupled with ideas from agency theory (Eisenhardt, 1989; Jensen and Meckling, 1976) and stewardship theory (Davis et al., 
1997a; Hernandez, 2012), we posit that the unintended undesirable consequences of PMSs are likely to occur when a system is designed using false assumptions about people's behaviour and the incidence of uncertainty. False assumptions may be due to ignorance, error, immediate short-term concerns, fundamental values and ideologies, or self-fulfilling forecasts. Invalid assumptions will lead to the adoption of control mechanisms that do not fit the "real" context, altering the existing social relationships that shape individual decisions and actions and, over time, creating unintended effects with overall costs that may outweigh the benefits.

Our work contributes to existing research in three important ways. Firstly, it provides some words of caution regarding the uncritical adoption of agency theory assumptions when designing PMSs. Secondly, it contributes to previous performance management contingency research (Chenhall, 2003; Otley, 2016) providing additional evidence regarding the importance of "fit" between control mechanisms and their environment. Thirdly, the study enriches our understanding of the effectiveness of PMSs by illuminating the reasons why unintended consequences may occur, so they can be minimized although never fully eliminated.

\section{Literature review methodology}

We initially contemplated using a systematic review approach, consisting of a methodical, transparent and reproducible literature search and synthesis process with "the twin aims of enhancing the knowledge base and informing policy making and practice" (Tranfield et al., 2003, p. 207). Systematic reviews have been praised for their usefulness in examining 'what works' (Gough, 2015), but their value for theory building has been highly criticised (Gough, 2015; Gough et al., 2012). When the purpose of a review is not only to investigate 'what works', but also to uncover the logic or mechanisms that explain 'why something works' (or 
does not work), systematic reviews may not be sufficient. For theory building some authors (e.g., Gough et al., 2012) suggest a systematic review can be complemented by a more eclectic review, allowing for a broader search for insights and "trial and error thinking and imagination" (Weick, 1989, p. 516). This alternative review method has been described as a "mixed method review" (Gough, 2015, p. 3) because it integrates some of the transparent and rigorous processes of systematic reviews (i.e., scoping study, selection of keywords and search streams, exclusion and inclusion criteria and quality assessment) whilst keeping the openness and scope of traditional reviews. Since our research has a theory building purpose, we adopted a mixed method review, consisting of both an eclectic literature review and a systematic review.

Our eclectic review had three key objectives, central to any theorising attempt (Shepherd and Suddaby, 2017; Weick, 1989): to clarify the meanings of core terms; to discover existing shared research assumptions; and to identify existing theories that could help in our theorising work. To address these objectives, we analysed performance management research and the sociology literature on theorising the unintended (Waddington, 2016). Our eclectic or traditional review process follows Ridley's (2012) suggestions and is outlined in Table 1. The insights from this review helped us to ascertain the language, concepts, known relationships and previous considerations needed for our theory development endeavour (Weick, 1989).

\section{INSERT TABLE 1 AROUND HERE}

Our systematic review focused on the unintended consequences of PMSs. We addressed two specific review questions: (1) what are the most common unintended 
undesirable consequences of PMSs? And (2) what is known about how and why they occur? We followed the advice of Tranfield et al. (2003) and Briner and Denyer (2012), with a full description of the process being presented in Table 1. We initiated the review with a scoping study in which we examined classic works on the unintended consequences of performance management. This helped to identify key search words and segments of the literature where relevant knowledge was more likely to exist. We then investigated the research that had cited these classic papers and also performed additional searches in the EBSCO library database using search strings. We conducted our searches for the years 1950-2017 to give us good coverage and to include the years when the emerging work on the unintended consequences of performance management was published.

When analysing the documents identified, we adopted a set of inclusion, exclusion and quality criteria. We included empirical and conceptual studies that provided insights about the dysfunctional unintended consequences of PMSs published in English. We excluded studies focused on the control of specific and narrow management processes or single functions (e.g., supply chains, production or marketing). We also excluded commentaries on books, erratum papers, introductory papers to special issues, and conference summaries. To ensure the quality of the work, we focused on studies considered $3^{*}$ and $4^{*}$ by the ABS Academic Journal Guide (see journal list in Table 1). To analyse the contend of each selected article, we first extracted critical information about the field of research, research method, context, control mechanisms studied, unintended consequences found, and explanations provided. We then adopted a thematic analysis and provided a narrative synthesis of our findings. The insights unearthed from both literature reviews are now presented. 


\section{Findings: Eclectic review}

We first synthesise the findings of our traditional review. These findings are presented in two separate sections: one dedicated to the insights unearthed from the general performance management literature; and another dedicated to the insights of the sociology literature on theorising unintended consequences.

\section{Performance management research}

When reviewing performance management research, we paid special attention to three areas considered to be critical for our subsequent theorising attempt: the meaning of PMSs, shared research assumptions, and the organizational theories that can help explain PMS consequences.

\section{Definition of a performance management system}

In any theorising endeavour, it is critical to clarify the meaning of core terms (Shepherd and Suddaby, 2017). In the literature, a PMS has been broadly defined as a set of management control mechanisms used by executives and employees with the overall purpose of facilitating the delivery of organizational goals by influencing people's behaviour and performance (Broadbent and Laughlin, 2009; Ferreira and Otley, 2009; Malmi and Brown, 2008). At the very least, a PMS comprises: a planning element, which includes the goals that reflect stakeholders' expectations and thus defines performance; a measurement element, which includes the metrics used to operationalize performance; a review element, which refers to the evaluation and feedback of performance information; and a performance-related reward element, which can be extrinsic (e.g., bonuses) or intrinsic (e.g., a clear sense of achievement) (Ferreira and Otley, 2009; Flamholtz et al., 1985; Otley, 1999). A PMS can also include further control elements, such as cultural and administrative controls (Malmi and Brown, 2008; Ouchi, 1979). 
It should be noted that the term ' $\mathrm{PMS}^{\text {'2 }}$ is of relatively recent origin and has emerged from a previous stream of literature that discussed what is known as 'management control systems' (Ferreira and Otley, 2009; Otley, 1999). We view these two terms as largely synonymous whilst noting that earlier work tended to focus on systems of financial and budgetary controls rather than on a wider range of organizational control mechanisms. This reflects the fact that formal control systems were rudimentary and relied primarily on financial data until the later 1980s. In this paper, we use the term 'PMS'. We view it as an overall system combining a variety of specific mechanisms that will vary from organization to organization.

\section{Shared research assumptions}

Theory building emerges from the identification and questioning of existing shared assumptions (Shepherd and Suddaby, 2017; Weick, 1989). The following assumptions of PMS research are particularly relevant as they provide a foundation on which to base our theoretical work.

Firstly, previous research largely regards each of the control mechanisms comprised in a PMS as a subsystem in its own right (e.g. measurement system, reward system)(Ferreira and Otley, 2009; Malmi and Brown, 2008; Otley, 1999). These sub-systems may have been designed by different people (e.g., HR managers, strategy managers, management accountants) and at different points in time. They may work differently within each of the organizational functions (and possibly locations), and at different hierarchical levels (Ferreira and Otley, 2009). It is often assumed that the overriding purpose of these separate subsystems

\footnotetext{
2 The literature in Human Resource Management often uses this term in the restricted sense of (annual) employee performance appraisal of a primarily developmental nature.
} 
is to act as a coordinated system to help the organization attain its goals, although such a complete integration is rarely achieved in practice (see Otley, 2016).

Secondly, the control mechanisms forming a PMS are considered to be connected to each other in a variety of ways (Ferreira and Otley, 2009; Malmi and Brown, 2008). Using the concepts of "tightly" and "loosely coupled" systems (Weick, 1976, p. 4), it can be suggested that some controls are tightly coupled (i.e., they are not only linked together in some ways, but they are also highly dependent on each other so that changes in one control lead to consequent changes in others) (Franco-Santos et al., 2014; Malmi and Brown, 2008; Otley, 2016). Other control mechanisms may be loosely coupled (i.e., they are subsystems that operate on an exchange relationship where little input is needed from each additional subsystem - that is, subsystems may interact but they are not dependent on each other to function adequately) (Franco-Santos et al., 2014; Malmi and Brown, 2008; Otley, 2016).

Thirdly, PMSs are constantly evolving (Cardinal et al., 2004; Ferreira and Otley, 2009). Control mechanisms that are seen to have deficiencies are improved or transformed (Chenhall and Euske, 2007). Changes are made on an on-going basis, often with the aim of aligning disparate subsystems with each other, or responding to new internal and external pressures (Chenhall, 2003; Otley, 2016). However, significant lags in alignment (or degrees of integration) may occur ${ }^{3}$; new control mechanisms may also be introduced that have their own differences from the extant controls; and the speed of integration often lags the rate of introduction of new elements (Otley, 2016).

Fourthly, the control mechanisms that comprise a PMS can be either formal or informal (Broadbent and Laughlin, 2009; Ferreira and Otley, 2009; Malmi and Brown, 2008).

\footnotetext{
${ }^{3}$ Pay for performance systems are particularly 'sticky' in this respect as they often require renegotiation with groups of employees and the measures used to drive performance-related pay are invariably slow to get updated.
} 
Formal control mechanisms (e.g., measures, targets, etc.) are considered tangible objects that can be controlled and easily changed. Informal control mechanisms (e.g., peer pressure, routines) are less tangible social phenomena that are more difficult to investigate and change (Chenhall and Morris, 1995; Kreutzer et al., 2016). In the literature, there appears to be a general understanding that formal control mechanisms are likely to have dysfunctional effects and these can be mitigated by the use of informal means of control (Kreutzer et al., 2016; Malmi and Brown, 2008). Despite this general understanding of the likely existence of unintended consequences, as suggested earlier, little appears to be known about how or why these consequences emerge.

Finally, PMSs are based on implicit or explicit mental models that predict likely outcomes (Otley and Berry, 1980). Individual managers each have their own mental models by which they decide upon particular courses of action because they predict these will lead to specific desirable outcomes. Different managers may often have markedly different predictive models, which may lead to different uses of control mechanisms (Hall, 2011). When organizations design central PMSs, their designers have cognitive schemas in their minds that reflect their own interpretation of organizational goals, together with their view of the drivers of organizational success and how these drivers relate to each other (Otley and Berry, 1980). Designers' models are often based on an array of assumptions about people, the environmental conditions under which the organization operates, and about the control mechanisms that best suit these drivers of organizational success (Broadbent and Laughlin, 2009).

\section{Seminal theories on the consequences of performance management systems}

For the development of new theory, it is important to review extant theories illuminating the phenomenon under study (Shepherd and Suddaby, 2017; Weick, 1989). When reviewing 
theories, we focused on those that provided general statements explaining PMSs existence and predicting their consequences. As such, three well-known organizational theories were identified: contingency theory of accounting (Otley, 1980, 2016), agency theory (Eisenhardt, 1989; Jensen and Meckling, 1976) and stewardship theory (Davis et al., 1997b; Hernandez, 2012).

The contingency theory of management accounting (Otley, 1980, 2016) argues that a 'universal approach' to the design and use of PMSs across and within organizations is unlikely to be effective. Control mechanisms are to be tailored to fit the specific circumstances of their use and context to deliver their intended consequences. Since the 1980s, an array of factors (or contingencies) has been shown to influence the design, use and consequences of control mechanisms (e.g. environmental uncertainty, task complexity) (Chenhall, 2003; Otley, 1980). Recent contingency research suggests that the number of factors influencing PMSs has expanded together with the complexity of these systems (Otley, 2016). As a result, the provision of precise prescriptions taking into consideration the increasing number of contingencies affecting PMSs is unlikely to be possible.

Most previous PMS research is underpinned by agency theory (Franco-Santos et al., 2012; Otley, 1999; Otley and Berry, 1980). Agency theory (Eisenhardt, 1989; Jensen and Meckling, 1976) explains the choice, use and consequences of organizational control mechanisms. According to the basic model of this theory ${ }^{4}$, organizations seek to fulfil the goal expectations of their owners and employees are assumed to be self-serving or opportunistic, effort-averse, and risk-averse. This situation generates a goal-alignment

\footnotetext{
${ }^{4}$ We acknowledge that there are different strands of agency theory and that over the years it has been extended to accommodate numerous developments. However, we noticed in the review of the literature that most performance management research interprets agency theory in terms of its basic model (Eisenhardt, 1989). This version of the theory is also the most commonly recognised by managers and by management scholars.
} 
problem and increases the uncertainty of outcomes as employees may "shirk" by putting in less effort, or by focusing on their own goals at the expense of owners' goals (Eisenhardt, 1989; Nilakant and Rao, 1994).

To address these issues, agency theory (Baiman, 1982; Eisenhardt, 1989), drawing mainly on the discipline of economics, suggests the use of two tightly coupled control mechanisms: monitoring systems including explicit goals, performance measures and targets that provide information and help to assess employee behaviour and the results of their actions; and incentive systems such as short-term bonuses or stock options to encourage employees to focus on the realization of the organization's goals. Previous research has referred to these control mechanisms as directive (Franco-Santos and Doherty, 2017, p. 2319).

Stewardship theory (Davis et al., 1997b; Hernandez, 2012) is another theory explaining the choice, use and consequences of control mechanisms; although it is often positioned as contrary to agency theory. It has its roots in psychology and sociology and suggests that the assumptions of agency theory are too restrictive to apply to many organizations and employees, so exclusive reliance on its ideas and proposed controls may lead to undesirable consequences (Davis et al., 1997b). Stewardship theory assumes organizations have multiple and complex goals, and employees can behave as stewards rather than agents, having "a shared sense of ongoing responsibility to multiple stakeholders, which affects a focus on collective welfare over the long term" (Hernandez, 2012, p. 176).

Stewardship theorists (Davis et al., 1997b; Hernandez, 2012) argue that goalalignment is not an issue stewardship type organizations need to resolve. Uncertainty is seen as the natural state of affairs, so organizations must learn how to respond and cope with it. Consequently, if there is no goal-misalignment and uncertainty cannot be 'managed', the adoption of monitoring and incentive controls is unnecessary; it may actually be 
dysfunctional undermining the positive attitudes of stewards (Hernandez, 2012). Rather than relying on agency type controls, stewardship theorists suggest that organizations may be better off by "fostering relationship-centred collaboration through shared leadership practices, promoting employees' collective responsibility for work outcomes, enabling employees to derive intrinsic benefits from working towards a valued end; and cultivating self-efficacy and self-determination through ongoing employee development" (Hernandez, 2012, p. 177). Due to the focus on facilitating performance rather than controlling it, this type of control has been labelled as enabling (Franco-Santos and Doherty, 2017).

The different control approaches suggested by agency and stewardship theories resonate with a series of apparent conceptual dichotomies that have been frequently mentioned in different management literatures although rarely considered in combination. For example, concepts such as 'technical' and 'social controls' (as in socio-technical systems) (Smith and Bititci, 2017) focus on different aspects of the design and use of PMSs, but suggest that both views need to be combined. 'Transactional' and 'relational' controls have been distinguished (Broadbent and Laughlin, 2009), with the first approach based on the assumption that business is conducted as a series of unrelated arm's length transactions, whereas the second recognizes the importance of continued relationships over time. 'Coercive' and 'enabling' (Adler and Borys, 1996) have also been used in previous works to refer to two different approaches of organising work in bureaucracies. Finally, the wellknown 'Theory X' and 'Theory Y' (McGregor, 1960) has been highly influential, with Theory $\mathrm{X}$ assuming that people must be coerced into behaving appropriately in an organizational context, and Theory $\mathrm{Y}$ assuming that people will naturally behave in a cooperative manner if treated appropriately. We do not see each of these pairs of contrasts as identical but regard them as displaying a significant degree of commonality that allows us to use the distinction between them as an underlying construct of considerable importance. 
Building on recent research (Franco-Santos et al., 2017) and for the sake of clarity, we will use the terms 'directive' and 'enabling' systems to describe this contrast whilst recognizing the much wider literature that is embodied in this overall idea.

Having synthesised the insights extracted from the performance management literature we now turn to examine the ideas acquired from the sociology literature on theorising unintended consequences.

\section{Unintended consequences research}

To better understand how and why the unintended consequences of performance management may be dysfunctional, we reviewed previous research focused on theorising unintended consequences. The management literature is largely silent on this topic (Franco-Santos et al., 2012) with most relevant research coming from sociology (Waddington, 2016). Sociology has been described as the social science most active in examining the "unrecognised, unintended and emergent consequences of goal-oriented action" or "the science of the unexpected" (Portes, 2000, p. 1). We narrowed our focus to the most well-known sociological work investigating core meanings, shared assumptions and theories of unintended consequences.

\section{Definition of unintended consequences}

An unintended consequence has been defined as "a particular effect of purposive action which is different from what was wanted the moment of carrying out the act, and the want of which was a reason for carrying it out" (Baert, 1991, p. 201). In other words, it is the outcome of a conscious action other than that foreseen and intended. The term 'purposive action' was initially used by politicians and economists (e.g., Smith, 1759), but it was the sociologist Robert Merton (1936) who popularised it and the concept is now widely use in social science research. It is also clearly relevant to PMSs investigations. 


\section{Shared assumptions}

Research focused on theorising unintended consequences often shares the following assumptions (Baert, 1991; Mica et al., 2011). Firstly, it assumes there is a recognised intention on the part of the person or actor carrying out an action. This intention is to improve the state of things. Secondly, it accepts that any action will unavoidably have unintended consequences. Some of these unintended consequences may be desirable or beneficial, whilst others may be undesirable or dysfunctional with the possibility of reaching a point where they become perverse (i.e., the opposite of the intended). Thirdly, it suggests that unintended undesirable consequences can be minimized, but never fully eliminated. Fourthly, it supposes that it is vital to theorise unintended undesirable consequences to avoid an overall result in which an action, policy or practice 'backfires' (i.e., does more harm than good). Most sociology research, therefore, focuses on the explanation of undesirable unintended consequences and the situations under which these consequences may frustrate the underlying intention of the actors (Baert, 1991). It is worth noting that most researchers equate unintended consequences with unanticipated, unforeseen or unexpected effects (Baert, 1991, p. 201).

\section{Existing theories of unintended consequences}

Most research explaining unintended consequences (Mackay and Chia, 2013; Mckinley and Scherer, 2000; Peattie et al., 2016; Perri, 2014) refers to the ideas introduced by Merton (1936, 1968, 1996), and later extended by Elias (1998). Both authors provide the bedrock for the theoretical developments of the unintended consequences of purposive action (de Zwart, 2015; Mica et al., 2011). Merton (1936, p. 894) contends that any "purposive social action" inevitably has unintended consequences. Thus, some unintended consequences may actually be expected or anticipated as they may have been taken into consideration when deciding on 
the action. This point is critical for PMS research and, as suggested by Baert (1991), most social research underplays it or completely ignores it.

Merton (1936) is the first scholar to provide a general theory of unintended consequences. His work is widely recognised as the point of departure for any theory of unintended consequences (de Zwart, 2015; Mica et al., 2011). He argues that unintended consequences result from the interplay between actions and the situation in which actions occur, which is an explanation that resonates with the idea of 'contingency fit' in management research (Donaldson, 2001; Drazin and Van de Ven, 1985; Otley, 2016). He further elaborates his theory suggesting that unintended consequences exist because actors cannot anticipate all that can happen as a result of their chosen actions. Merton identifies five factors that may limit actors' possibilities to anticipate the full consequences of their actions: (1) actors may not have sufficient knowledge or they may ignore the knowledge they have; (2) they may err in the appraisal of the present and future situation, in the selection of a course of action or in the execution of the action chosen; (3) they may have an acute concern with the foreseen immediate or short-term consequences and give little consideration to longer-term outcomes, which Merton (1936) labels as the 'imperious immediacy of interest'; (4) actors may have fundamental values, which justify the felt necessity of certain actions; and (5) actors may take into consideration a preconceived idea suggesting particular outcomes and this prediction in itself becomes a new element in the concrete situation which subsequently makes the prediction accurate ('a self-fulfilling prophecy'). Merton suggests that these factors are not mutually exclusive and may reinforce each other.

The extension that Elias $(1997,1998)$ applies to Merton's $(1936,1968,1996)$ work is crucial as he provides a clearer explanation of the way in which purposive social action creates unintended undesirable consequences (Mica et al., 2011). Elias argues that unintended consequences mainly occur due to the social relationships existing in any group of people. 
People's knowledge of the social relationships in which they operate is unavoidably imperfect, incomplete and inaccurate. Therefore, their actions, which are based on their inadequate knowledge, more often than not, will have consequences they do not foresee (Mennell, 1977). Elias argues that the consequences of intended actions can only be understood by investigating the dynamics of social relationships. Equally, people's behaviour can only be understood in relation to the social relationships in which they operate. Intended actions bring about changes to social relationships, and social relationships in turn influence people's behaviour not always in the way intended. In short, Elias contends that unintended consequences of intended actions will always occur and that these consequences, together with the intended ones, create the basis for future action.

Bringing Merton's and Elias' ideas closer to our research, it can be argued that the development and use of PMSs involves purposive social actions and that these actions will have both intended and unintended consequences. As researchers, we need to strive to explain the occurrence of these consequences; and, in particular, the occurrence of undesirable or dysfunctional consequences, so we can minimize abnormalities. The use of Merton's limiting factors leading to unintended consequences together with Elias' focus on the importance of social relationships dynamics are instrumental for the purpose of our theory. However, as they recommend, further insights about the specific unintended consequences of particular purposive actions are needed in any theorising attempt supporting the need for a systematic review of the unintended consequences of PMSs. The next section describes the key findings from our systematic review.

\section{Findings: Systematic review}

Our systematic review had two key objectives. Firstly, to identify the most common unintended consequences of PMSs, and secondly, to analyse what is known about how and 
why they occur as reported in the performance management literature. Performance management research has identified a number of unintended undesirable consequences over the years (see Table 2). A priori, it is interesting to note that this literature interprets the concept of 'unintended consequences' as the negative unexpected effects of PMSs, which implies that the analysis of unintended beneficial consequences as such has been largely overlooked. The literature also seems to focus (not always explicitly) on the 'directive' control mechanisms endorsed by agency theorists (Eisenhardt, 1989; Jensen and Meckling, 1976); and it is mainly published in management accounting, general management, and

public-sector management journals. Most studies concentrate on how the use of performance measures and targets linked to monetary incentives (i.e., directive or agency theory-related systems) may have unexpected negative outcomes, especially in complex environments. Little has been said about unintended consequences emanating from 'enabling' or stewardship theory-related controls (e.g., peer pressure, cultural controls).

\section{INSERT TABLE 2 AROUND HERE}

\section{The unintended consequences of performance management systems}

From our literature analysis and thematic coding five salient dysfunctional unintended consequences of PMSs emerged. Firstly, directive PMSs have been shown to produce strategic behaviour or gaming as individuals alter the way in which they behave to fulfil performance expectations, sometimes to the point of breaching ethical norms (Berliner, 1956; 
Hood, 2006; Jensen, 2003). In total $81^{5}$ percent of the literature selected identified gaming as a major unintended consequence. Interestingly, not all studies presented gaming as perverse. A reduced set (e.g., Berliner, 1956) treated it as a 'necessary evil' worth having for the effort gains obtained from PMSs.

Secondly, directive PMSs appear to be associated with various forms of information manipulation (Cardinaels and Yin, 2015; Hood, 2006; Jensen, 2003; Kalgin, 2016; Smith, 1995a). Performance information is often misrepresented, misinterpreted, reclassified or made up in order to meet performance requirements. 74 percent of the literature reviewed mentioned this unexpected consequence. The deliberate manipulation of data can range from creative accounting to clear fraud. Concepts such as 'fiddling' (Mannion and Braithwaite, 2012), 'managing the numbers' (Jensen, 2003; Li, 2015) or plain 'dishonesty' (Hannan et al., 2006) are common in this body of work.

Thirdly, directive PMSs are likely to generate selective attention with 55 percent of our selected articles referring to this phenomenon. Selective attention occurs both in terms of 'what' is measured and in terms of 'when' is measured. Managers appear to become fixated on performance measures and targets that are quantified or formally considered in PMSs, causing those aspects of organizational goals that are not (or cannot be) measured to be overlooked (Hood, 2006; Kerpershoek et al., 2016; Mannion and Braithwaite, 2012; Smith, 1995a). They also tend to focus on actions that focus on short-term goals (or what in the literature is described as 'short-termism' or 'myopia' (Merchant, 1990)), rather than selecting

\footnotetext{
${ }^{5}$ It should be noted that this percentage reflects the degree of attention that each consequence has received in the literature. It does not necessarily reflect the importance of each consequence or its relevance in the process for creating perverse outcomes for the organization.
} 
actions which may have greater long-term benefits but smaller (or even negative) impacts in the short-term.

Fourthly, directive systems often produce an illusion of control. Over time, the use of these controls leads managers to believe their assumptions about performance, its measurement, and accountability are applicable to their organization. These premises give way to the idea that PMSs accurately and validly reflect 'actual' performance (Chwastiak, 2006; Cugueró-Escofet and Rosanas, 2017; Hood, 2006). This unintended consequence is cited by 24 percent of the studies included in the review. The illusion of control is often perverse, especially, in highly uncertain and complex environments.

Finally, 81 percent of our selected studies suggest that both directive and enabling PMSs are likely to alter the social relationships operating in organizations. For instance, Chwastiak (2006) and Conrad and Guven (2012) found the PMSs studied, which were focused on monitoring through performance measures, targets and incentives (i.e. agency theory related), promoted transactional relationships, diminishing trust as well as generating inequalities and differentiation. By contrast, Segal and Lehrer (2012) show how the transition from an agency-related performance management approach to a stewardship-related approach in a Canadian school district led to a transformation in the social relationships experienced by staff from mistrust and alienation to high trust and benevolence, decreasing corruption and other unintended effects.

Other unintended consequences of directive PMSs less prominent in the literature are: administrative overload and managerial time costs due to the design, implementation and use requirements of the system (e.g., Cox, 2005; Hansen et al., 2003); de-professionalization or movement away from professional values and standards (Agyemang and Broadbent, 2015; Tan and Rae, 2009); decreased well-being and morale (Bonner and Sprinkle, 2002; FrancoSantos et al., 2017); 'ossification' (i.e., tendency towards being in a rigid state, constraining 
responsiveness and resisting change) (Mannion and Braithwaite, 2012; Smith, 1995b); stifled innovation (Lindsay et al., 2014); and injustice, unfairness and inequalities (Cugueró-Escofet and Rosanas, 2016).

In comparison with the amount of work conducted in the for-profit sector on the intended consequences of PMSs (Franco-Santos et al., 2012), it is noticeable that a large proportion of the research on unintended dysfunctional consequences has taken place in public sector organizations. In these organizations, the unintended consequences of PMS mechanisms were deemed to be perverse (rather than necessary evils), not just for the users of the system, but also for other stakeholders (e.g. public, patients, students, society in general) (e.g., Conrad and Guven Uslu, 2012). In for-profit organizations, the predominant undesirable unintended consequences studied were related to information manipulation, strategic behaviour and short-termism (Healy, 1985; Jensen, 2003; Lowe and Shaw, 1968).

\section{Explanations of how and why unintended consequences occur}

Most extant research describes undesirable unintended consequences of performance management, but very few scholars provide in-depth explanations about how and why these consequences emerge in the first place. Nevertheless, after carefully reading and interpreting the literature selected, the following insights can be extracted. Most scholars relate the occurrence of unintended consequences to an increase in managers' perceived pressure ( $\mathrm{Li}$, 2015; Merchant, 1990); the particular design or use of the PMS (Hopwood, 1972; Mannion and Braithwaite, 2012; Schwepker and Good, 2012); and environmental complexity (Conrad and Guven Uslu, 2012; Cox, 2005; Tan and Rae, 2009). Each of these reasons is examined in turn.

There is some consensus on the idea that managers perceived high performance pressure when directive PMSs are in operation (Merchant, 1990). Managers may interpret the 
presence of high pressure as a threat (more so when there are known penalties for not reaching targets such as lower pay or reduced opportunities for promotion). If they feel there are possibilities for non-compliance, they may choose to do things that in other circumstances they would not do (e.g., gaming, lying) (Carmichael, 1970). Over time, these behaviours may be internalised and rationalised, affecting trust and social interactions (Cardinaels and Yin, 2015). In some contexts, gaming and low-trust environments are considered a 'price worth paying' (Berliner, 1956) or 'part of business life' (Jensen, 2003). In others, high-trust social relationships are paramount (e.g., hospitals, schools, universities) and, when these relations are changed, perverse effects may appear (McCann et al., 2015).

Many scholars argue that unintended consequences are due to issues associated with the particular design or use of PMSs (Berliner, 1956; Chow et al., 1988; Hopwood, 1972; Kalgin, 2016). For instance, the link between performance measurement and rewards is found to be a critical choice that can lead to negative unintended consequences (Berliner, 1956; Jensen, 2003; Kerpershoek et al., 2016). Scholars have noticed that people's sense of gain (or loss) associated with performance-related rewards can lead to strategic behaviour, affecting coordination, collaboration and social dynamics (Lowe and Shaw, 1968). It can generate feelings of unfairness and injustice pushing people in the wrong direction (Cugueró-Escofet and Rosanas, 2017). Hopwood (1972) highlights that including performance information in the performance management process does not necessarily lead to dysfunctionalities, rather arguing that these are caused by the way in which such data is used. He finds that using data in ways that enable learning rather than with the sole purpose of controlling individuals leads to less data manipulation.

A few researchers suggest that unintended consequences are due to complexity and uncertainty issues. For example, Merchant (1990) argues that managers operating in uncertain environments were significantly more likely to react to budget pressure by gaming 
the system. Berliner (1956) observes that the continuous change in leaders created increased uncertainty and more opportunities for gaming. The work of Tan and Rae (2009) also suggests that in highly complex and regulated organizations such as airports, hospitals or education institutions the use of directive PMSs is more likely to create side effects. They argue this is due to aspects such as measurement difficulties (i.e., not everything that matters can be measured, and existing measures might be 'noisy' or distorted), diverse stakeholders' needs which cannot always be reconciled, or conflicting targets.

Together with these common explanations, a few researchers assert the unintended consequences of a direct PMS are associated with its underlying assumptions about people's behaviour (Cardinaels and Yin, 2015; Franco-Santos et al., 2017; Kerpershoek et al., 2016; Lindsay et al., 2014). Rooted in agency theory, directive mechanisms are tools to help managers (i.e., principals) control the performance of employees (i.e., agents), who are assumed to be opportunistic (Kerpershoek et al., 2016). By choosing directive controls (i.e., measures, targets, individual reviews, incentive pay), managers are indirectly sending a message to employees about the needs for control implying that employees cannot be trusted. At the individual level, this choice of controls may indicate to employees that others are behaving opportunistically, which in turn may influence their own behaviour. As suggested by Cardinaels (2015), the belief that employees in general are opportunistic (i.e., agents) will change social norms and, over time, people will conform or internalised these norms increasing their self-interested behaviour. In 'mission-oriented' organizations (e.g., hospitals, schools, universities), where professionals and professional values often dominate (i.e., people more likely to behave as stewards rather than agents), false theories about people's behaviour, the importance of relationships and the real complexity of the context, can be the grounds for the unintended consequences of direct controls to become perverse (Chwastiak, 2006; Franco-Santos et al., 2017; Kerpershoek et al., 2016; McCann et al., 2015). 
Notwithstanding these varied rationalisations, researchers appear to have shied away from providing specific predictions (i.e., a theory) relating not just directive PMSs to unintended consequences, but also enabling PMSs to their own unintended consequences. The absence of theorising, may be partly due to the multidimensional and complex nature of explanatory factors and their potential relationships. Based on the insights extracted from both of our reviews (see Table 3 for a summary), we now attempt to provide such a theory.

\section{INSERT TABLE 3 AROUND HERE}

\section{Towards a new theory of the unintended}

Before explaining our suggested theoretical framework, we find it necessary to clarify our style of theorising. We believe this clarification will help to improve the transparency of our theorising process and, hopefully, avoid misunderstandings.

\section{Style of theorising}

As suggested by Cornelissen (2017, p. 2), "at its core, a style [of theorising] is a particular form of argumentation that we use to structure our thinking and express our ideas about a management or organizational phenomenon in a common idiom". Such an idiom can take the form of propositions, a narrative of a series of interconnected processes or a typology (Cornelissen, 2017; Delbridge and Fiss, 2013; Shepherd and Suddaby, 2017). All three styles of theorising have their benefits and limitations (Cornelissen, 2017). We have chosen to derive our theory of the unintended consequences of PMSs following a typology style because of the complexity and multidimensional nature of the mechanisms at play which made the other two theorising options less suitable (Cornelissen, 2017). 
A typology style of theorising proceeds by "categorizing and clustering ideas and observations to offer a multidimensional take on a management or organizational subject" (Cornelissen, 2017, p. 6). Typologies are "conceptually derived, interrelated sets of ideal types. [...] [Each ideal type] represents a unique combination of the organizational attributes that are believed to determine the relevant outcome(s)" (Doty and Glick, 1994, p. 232). A typology style allows us to move beyond traditional linear or interaction theories and to incorporate the multiple contingencies that are likely to relate to the unintended consequences of PMSs. This type of theorising assumes that the "way organizational factors fit together is very important and that to understand organizations we must consider simultaneously multiple characteristics" (Doty and Glick, 1994). Another important aspect of typological theories is that they incorporate the idea of 'equifinality' (i.e., different ideal types can reach the same outcome following different paths)(Drazin and Van de Ven, 1985).

Good typologies provide explanations at two different levels: At one level, they provide a grand theory generalizable to all organizations; at another level, they include a set of middle-range theories restricted to the individual ideal types (Doty and Glick, 1994). In many cases, grand theories are implicit and state that particular configurations grouped into ideal types maximise 'fit' and can explain the outcome(s) (e.g., Miles and Snow, 1978). Middle-range theories have narrower boundaries and explain the internal consistency of the underlying mechanisms operating within each ideal type (Doty and Glick, 1994). These theories may be based on different assumptions and the pattern of relationships that explain a particular ideal type does not necessarily need to generalize to all the ideal types or to all organizations (Doty and Glick, 1994).

As described earlier, the process of theory development can be initiated with a thorough review of the literature, but it needs to be accompanied by other less observable cognitive processes occurring simultaneously as the theorist interprets the evidence and 
makes sense of it, creating connections and making generalisations (Shepherd and Suddaby, 2017; Weick, 1989). We present the results of our theory development process next.

\section{Theorising the unintended consequences of performance management}

In this section we make explicit our grand theoretical assertion, we define the key dimensions that form the basis of our typology, and we examine the middle-range theories that predict each ideal type.

\section{Grand theoretical assertion: The importance of fit}

As shown in our review, the contingency theory of management accounting (Chenhall, 2003; Otley, 1980, 2016) is an overarching theory underpinning most research in PMSs. This theory is based on the premise that the control mechanisms co-existing to form a PMS need to be tailored to fit the specific circumstances of the organization. The better the 'fit' between a PMS and its contingencies, the greater its effectiveness will be (i.e., the degree to which its intended results are achieved) (Otley, 1980, 2016). Building on these ideas, our grand theoretical assertion is that an identified set of ideal PMSs types will maximize the fit between the chosen control mechanisms and the existing organizational conditions

Knowing that a better fit will drive better results does not mean that, in practice, organizations will design the systems that are meant to be best for their circumstances. Managers may (inevitably) have imperfect knowledge of the organization, its context and its people; they may make mistakes when analysing the organization or when choosing the control mechanisms that best fit organizational conditions; they may have immediate or short-term pressures, discounting the importance of long-term effects; they may be biased by particular values or ideologies; or their own believes may lead to self-fulfilling prophecies (Merton, 1936). Because of these limiting factors, managers will make specific choices between alternatives resulting in PMSs that may be (to various degrees) not fully aligned with 
the situations they are meant to deal with. Thus, managers cannot anticipate all that can happen to avoid potential issues and, inevitably, unintended consequences will appear. Following Merton's (1936) logic, some of these unintended consequences can be predicted and curtailed through careful theorising about the "purposive action" and the situation or context in which the action takes place. Therefore, if we assume a PMS to be a "purposive action" (i.e., a deliberate act intended to cause change, which in this case is to improve performance): how can we predict the unintended consequences of a PMS, especially those that can lead to dysfunctionalities making it a perverse system?

To address this question, we go back to the idea that there is variability in the type of control mechanisms organizations design and use (Bedford et al., 2016; Broadbent and Laughlin, 2009; Ferreira and Otley, 2009; Malmi and Brown, 2008). Some organizations heavily rely on performance monitoring and extrinsic rewards whilst others rely on other more enabling means to deliver their mission and performance (Franco-Santos et al., 2014; Frey et al., 2013). We suggest that organisations relying on directive PMSs in highly uncertain contexts are likely to experience more undesirable unintended consequences not just for managers but also for other stakeholders (Mannion and Braithwaite, 2012; Smith, 1995a). The findings of our reviews can help us explain this phenomenon.

Key dimensions: goal-alignment and goal-uncertainty

Our conjecture is that when organizations develop their PMSs, managers base their decisions about which control mechanisms to introduce on two key factors. As suggested by agency theory (Eisenhardt, 1989; Jensen and Meckling, 1976), they make assumptions about the existing level of goal-alignment (i.e., how aligned they believe the goals or interests of employees are to the goals of the organization). Whilst it is recognized that goal-alignment can never be perfect (for example, the trade-offs between conflicting goals need to be 
continually re-evaluated and communicated ${ }^{6}$ ), it is likely that the degree of goal-alignment will differ between and within organizations depending on their circumstances.

Managers also make assumptions about goal-uncertainty (i.e., how much uncertainty exists in managers' predictive models). Managers assess their environment and the measurability of organizational goals, developing predictive models (explicitly or implicitly), which define what the organization is aiming for, identify a plan to achieve it, and attempt to estimate what is likely to occur when such a plan is implemented. Since complete information is rarely available, managers need to take into account the uncertainty that exists in their models. Based on their predictive models and assumptions about people's behaviour, managers make choices among alternatives of control mechanisms and decide how to act (Broadbent and Laughlin, 2009).

\section{Middle range theories}

Based on the insights extracted from the literature (Cardinaels and Yin, 2015; Kerpershoek et al., 2016; Lindsay et al., 2014; McCann et al., 2015), it can be argued that the unintended consequences of PMSs occur in situations where managers' 'assumed' reality differs from the 'real' states of affairs or observed reality. How this difference comes about can again be explained by the limiting factors suggested by Merton (1936) (i.e., ignorance, error, fundamental values or ideologies, an acute focus on short-term consequences, and the existence of a self-fulfilling prophecy). This divergence affects the interplay between the chosen control mechanisms and the situation in which these mechanisms operate, decreasing

\footnotetext{
${ }^{6}$ For example, taking the well-known trio of objectives in a project management perspective, that is quality, cost and time, the emphasis placed on each will vary considerably over the course of a project. Such changes in priorities will need to be communicated to employees so that they can respond appropriately in the specific situations they are dealing with.
} 
its fit. How and why this divergence generates dysfunctionalities is discussed below. We illustrate our overall conceptual framework using Figure 1.

\section{INSERT FIGURE 1 ABOUT HERE}

In situations where managers assume low goal-alignment (believing that employees behave opportunistically) and low goal-uncertainty (in terms of the accuracy of their predictive model of outcomes), we expect to find greater reliance on the control mechanisms suggested by agency theory (i.e., directive PMSs which include specific goals, measures and targets, incentive pay). These control mechanisms may be appropriate in highly programmed and well-understood situations (although the varieties of human response may make even this problematic), but they may run into severe difficulties when applied to situations where the opposite contingencies exist. One example can be the R\&D function of a large pharmaceutical company, where the mechanisms used for managing performance may need to be radically adapted to cope with managing long-term projects with highly uncertain outcomes and staffed by committed professionals.

It may happen that the assumed situation reflects the premises of agency theory (i.e., self-serving behaviours, risk-aversion, maximisation of financial short-term goals) and the 'real' organization represents the conditions of stewardship theory (i.e., shared interests and responsibilities, complex and long-term oriented mission and goals, many of which are nonfinancial). In this extreme situation, the adoption of directive controls may significantly alter the organizational social 'fabric' and relationships. The choice of directive controls will send the message that people are not to be trusted, which, over time, may turn out to be true (Cardinaels and Yin, 2015). The increased pressure coupled with the high uncertain 
environment and feelings of injustice may encourage employees to retaliate and exhibit the behaviours the system is intending to control. This situation will eventually transform the social dynamics (Argyris, 1953; Tan and Rae, 2009) and, as suggested by Elias (1998), the change in social dynamics will increase the likelihood of perverse unintended consequences.

In situations where managers assume high goal-alignment implied from their beliefs of employees behaving as stewards (i.e., exerting long-term oriented, prosocial behaviours (Davis et al., 1997b; Hernandez, 2012)) and high goal-uncertainty; we expect to find an enabling PMS as suggested by stewardship theory. However, when managers' taken for granted assumptions do not correspond with the observable or actual reality, social relationships will be altered leading to unintended undesirable consequences. For instance, in a university when high autonomy and collegiality (i.e., enabling controls) are applied to parts of the institution that have not been socialised into the academic profession and its internalised values and standards, the consequences of this stewardship-related controls may not be those intended and 'free riding' effects may appear.

In situations where managers assume low (high) alignment and high (low) uncertainty, we expect to find hybrid PMSs. Hybrid systems will combine features of enabling and directive PMSs with a stronger tendency towards one or other of them depending on the presumed circumstances. Examples of hybrid systems can be the systems suggested for third sector organizations (e.g., Lindsay et al., 2014) whose leaders (and designers of the PMS) believe that employees and volunteers are highly aligned with the cause but at the same time need to produce and report financial results and predictable outcomes to demonstrate the value of their work to current and future donors or funders. If the assumed situation corresponds to the actual situation, we expect that unintended undesirable consequences will be minimized due to the use of a wide range of controls, which 
will be more adapted to the needed diversity in social relationships. However, if it does not, a set of unintended dysfunctional consequences will emerge.

For simplicity, we have so far assumed that reliance on directive controls and reliance on enabling controls are independent dimensions so that a choice to emphasize one does not imply a lower emphasis on the other, although there are probably constraints on the total amount of control used by any single organization (Franco-Santos et al., 2014). Perhaps, a more realistic position is to argue that how organizations choose to emphasize each of these two ideal types of systems is an empirical issue that cannot be theorised in detail and in advance, thus suggesting an important focus for future research.

\section{Discussion}

Performance management is an important phenomenon in organizational research and management practice (Otley and Soin, 2015; Smith and Bititci, 2017). Most earlier research has been devoted to the prediction of the intended consequences of a PMS, whilst limited attention has been given to the explanation of its unintended consequences (Franco-Santos et $a l ., 2012)$. The aim of this paper is to develop a theory of the unintended undesirable consequences of PMSs based on a mixed review of the literature.

Based on our mixed review of the literature, we propose that managers design and use PMSs based on two key assumptions. They make their choices according to their beliefs about goal-alignment (i.e., how aligned they believe the goals or interests of employees are to the interests of the organization) and about goal-uncertainty (i.e., how much uncertainty exits in managers' predictive models). Based on these assumptions, managers introduce different combinations of the controls available to them. As Merton (1936, p. 901) asserts, management controls "predicated upon imaginary conditions must inevitably evoke unexpected consequences". The gravity and nature of the unintended undesirable 
consequences will depend on how and on how much managers' assumed reality differs from the 'real' state of affairs. In sum, we argue that a false or misguided definition of the control situation, leads to the selection and use of a set of control mechanisms that, over time, generate unintended consequences transforming the existing social relationships, which can ultimately lead to perverse outcomes.

We contribute to the literature on PMSs in various ways. Firstly, we question the validity of the common agency theory related assumptions underpinning much performance management research. People are not always opportunistic, the mission of an organization might not be to maximise its financial performance, and uncertainty is not always manageable through directive control mechanisms. Our typology suggests that using agency theory assumptions as the default position when designing and using PMSs may often be problematic. This has important implications for public sector entities focused on developing complex missions such as hospitals, schools or universities and known to be guided by professional values and standards. Further research could be devoted to the improvement of the design and use of PMSs so critical assumptions in managerial mental models are surfaced and questioned before key choices are made. Unintended consequences will always exist, but improved design and use processes may avoid them doing more harm than good.

Secondly, the general idea behind our work connects with previous contingency research (Chenhall, 2003; Otley, 2016), indicating that appropriate control systems are unlikely to be universal. They need to be adapted to the circumstances in which they are being used and to the objectives being sought. PMSs are inherently complex, with different approaches to control being appropriate in different organizational functions, in varying organizational environments, and at different hierarchical levels. This assertion is in line with Ouchi's $(1977,1980 ; 1978)$ ideas on the various configurations of controls according to context; and with more recent management control (Bedford et al., 2016; Bedford and 
Malmi, 2015; Malmi and Brown, 2008) and operations research (Smith and Bititci, 2017) looking at the configuration of performance management packages.

Thirdly, previous research has tended to concentrate on the nature of unintended outcomes rather than on the reasons underlying their existence. Based on our review, it is likely that a richer explanation could be given by considering various aspects of the context within which control is exercised. We would suggest that studies of how control works in different parts of the same organization (e.g. different geographical sites and locations, different business function, and different hierarchical levels) would give insights into this important phenomenon. Given the complexity of both PMSs and organizational contexts, it is suggested that studies which control for as much of this potential variation as possible (e.g. by using different parts of the same organization, or analysing difference within the same unit at different hierarchical levels) would likely give the most useful initial results. We hope that the framework put forward here will assist in this endeavour.

Our work is not free from limitations. The purpose of this paper was to develop new theory, but it was limited by being able to examine only a fraction of the considerable amount of literature that exists across a range of disciplines. In our search for insights and potential connections, we combined a traditional review of the conceptual performance management literature and the sociological research on unintended consequences with a systematic review focused on the identification of the most salient unintended undesirable consequences of PMSs. This mixed review approach means that there may be parts of our work that may not be reproducible, which is a common situation in theory building undertakings (Weick, 1989). We restricted our review to research published in English using a narrow set of keywords due to the volume of knowledge we were attempting to review. Based on this choice, relevant research that may have been found using alternative concepts to the ones used (e.g., side effects, performance appraisals) may have been omitted. Additionally, we took the decision 
to limit the scope of our review to research focused on overall corporate PMSs, which means that some unintended consequences of systems dedicated to the management of particular functions or processes (e.g., supply chain, marketing, new product development or production) have not been considered.

Going forward, it seems evident that further PMSs research investigating the unintended will yield both new contributions to theory and prescriptions for practice. New research could take the form of qualitative studies focusing on the performance management practices and the unexpected consequences that can be observed to emerge in organizations (Ashton, 1976). Real control systems attempt to cope with both complexity and uncertainty, and to integrate a variety of control mechanisms. This implies that case studies of performance management practices that attempt to take a holistic approach (i.e. attempting to include all control mechanisms being used) will be an important way forward. The theory outlined in this paper is intended to help provide a useful encompassing framework that will assist such program of work, but it needs to be supplemented by empirical work that pays attention to the idiosyncrasies of the situations in which different organizations and their PMSs operate.

\section{Conclusion}

This research is intended to help explain how, why and when PMSs lead to unintended consequences some of which can be perverse. All PMSs will have both intended and unintended consequences. We found that directive systems are likely to produce gaming, information manipulation, selective attention, illusion of control, and transform social relationships. Most previous research has focused on the intended effects of these systems but both types of consequences require researching and theorising as they both vary in how beneficial they are for an organization. Borrowing from the sociology literature on the 
unintended and well-known theories underpinning performance management processes (contingency, stewardship and agency theories) our general conclusion is that unintended undesirable consequences are likely to occur when a system is designed or used in circumstances that differ from those originally assumed. At the extreme, we suggest that the misrepresentation of a stewardship-type context as an agency-type context or vice-versa will lead to unintended undesirable consequences and this situation can make the resultant PMS perverse. Our main argument is that incorrect assumptions will lead to the design of 'unfit' control mechanisms, which will alter the existing social relationships influencing individual behaviour and ultimately lead to undesirable consequences or 'collateral damage' that may outweigh the intended outcomes.

Given that goal-alignment and goal-uncertainty conditions are likely to differ from organization to organization, within different parts of a single organization, and over time, the outcomes associated with the use of a particular PMS are also likely to differ. Studies on the reasons for such difference in outcomes, rather than reports of their occurrence, are relatively rare. Most research to date has concentrated on improving PMSs by examining how and why intended consequences occur. Our work suggests that we need to pay similar attention to the unintended undesirable consequences of PMSs, so the risks can be reduced. At present, due to the complexity of most organizations, we speculate that the safest approach for performance management designers might be one where balance is maintained between the use of both directive and enabling systems. It is hoped that the framework proposed in this paper will provide a stimulus and some guidance for conducting further research in this area. 


\section{References}

Adler, P. S. and Borys, B. (1996). Two Types of Bureaucracy: Enabling and Coercive, Administrative Science Quarterly, 41, pp. 61-89.

Agyemang, G. and Broadbent, J. (2015). Management control and research management in universities: An empirical and conceptual exploration, Accounting, Auditing \& Accountability Journal, 28, pp. 1018-1046.

Ahn, H. (2001). Applying the balanced scorecard concept: An experience report, Long Range Planning, 34, pp. 441-461.

Argyris, C. (1953). Human problems with budgets, Harvard Business Review, 31, pp. 97110.

Ashton, R. H. (1976). Deviation-amplifying feedback and unintended consequences of management accounting systems, Accounting, Organizations \& Society, 1, pp. 289-300.

Baert, P. (1991). Unintended consequences: A typology and examples, International Sociology, 6, pp. 201-210.

Baiman, S. (1982). Agency research in managerial accounting: a survey, Journal of Accounting Literature, 1, pp. 154-213.

Bedford, D. S. and Malmi, T. (2015). Configurations of control: An exploratory analysis, Management Accounting Research, 27, pp. 2-26.

Bedford, D. S., Malmi, T. and Sandelin, M. (2016). Management control effectiveness and strategy: An empirical analysis of packages and systems, Accounting, Organizations \& Society, 51, pp. 12-28.

Berliner, J. S. (1956). A Problem in Soviet Business Administration., Administrative Science Quarterly, 1, pp. 86-101.

Berry, A. J., Coad, A. F., Harris, E. P., Otley, D. T. and Stringer, C. (2009). Emerging themes in management control: A review of recent literature, British Accounting Review, 41, pp. 220.

Bevan, G. and Hood, C. (2006). Articles What's Measured Is What Matters: Targets and Gaming in the English Public Health Care System, Public Administration, 84, pp. 517-538.

Bonner, S. E. and Sprinkle, G. B. (2002). The effects of monetary incentives on effort and task performance, Accounting, Organizations and Society, 27, pp. 303-345.

Bourdieu, P. (1977). Outline of a Theory of Practice. Cambridge, UK.: Cambridge University Press.

Bourgeois, L. J. (1979). Toward A Method Of Middle-Range Theorizing., Academy of Management Review, 4, pp. 443-447.

Briner, R. B. and Denyer, D. (2012). Systematic review and evidence synthesis as a practice and scholarship tool. In Rousseau, D. (ed),The Oxford Handbook of Evidence-based Management. Oxford, UK: Oxford University Press, pp. 112-129.

Broadbent, J. and Laughlin, R. (2009). Performance management systems: A conceptual model, Management Accounting Research, 20, pp. 283-295.

Cardinaels, E. and Yin, H. (2015). Think Twice Before Going for Incentives: Social Norms and the Principal's Decision on Compensation Contracts, Journal of Accounting Research, 53, pp. 985-1015.

Cardinal, L. B., Sitkin, S. B. and Long, C. P. (2004). Balancing and rebalancing in the creation and evolution of organizational control, Organization Science, 15, pp. 411$431+495$.

Carmichael, D. R. (1970). Behavioral hypotheses of internal control, The Accounting Review, 45, pp. 235-245.

Chenhall, R. H. (2003). Management control systems design within its organizational 
context: findings from contingency-based research and directions for the future, Accounting, Organizations \& Society, 28, pp. 127-168.

Chenhall, R. H. and Euske, K. J. (2007). The role of management control systems in planned organizational change: An analysis of two organizations, Accounting, Organizations \& Society, 32, pp. 601-637.

Chenhall, R. H. and Morris, D. (1995). Organic decision and communication processes and management accounting systems in entrepreneurial and conservative business organizations, Omega, 23, pp. 485-497.

Chow, C., Cooper, J. . and Waller, W. S. (1988). Participative Budgeting: Effects of a Truth Inducing Pay Scheme and Information Asymmetry on Slack and Performance, The Accounting Review.

Chow, C. W., Kato, Y. and Merchant, K. a. (1996). The use of organizational controls and their effects on data manipulation and management myopia: A Japan vs U.S. comparison, Accounting, Organizations and Society, 21, pp. 175-192.

Chwastiak, M. (2006). Rationality, performance measures and representations of reality: Planning, programming and budgeting and the Vietnam war, Critical Perspectives on Accounting, 17, pp. 29-55.

Conrad, L. and Guven Uslu, P. (2012). UK health sector performance management: Conflict, crisis and unintended consequences, Accounting Forum, 36, pp. 231-250.

Cornelissen, J. (2017). Editor's Comments: Developing propositions, a process model, or a typology? Addressing the challenges of writing theory without a boilerplate, Academy of Management Review, 42, pp. 1-9.

Cox, A. (2005). The outcomes of variable pay systems: tales of multiple costs and unforeseen consequences, The International Journal of Human Resource Management, 16, pp. 14751497.

Crabtree, A. D. and DeBusk, G. K. (2008). The effects of adopting the Balanced Scorecard on shareholder returns, Advances in Accounting, 24, pp. 8-15.

Cruz, I., Scapens, R. W. and Major, M. (2011). The localisation of a global management control system, Accounting, Organizations \& Society, 36, pp. 412-427.

Cugueró-Escofet, N. and Rosanas, J. (2017). The Ethics of Metrics: Overcoming the Dysfunctional Effects of Performance Measurements Through Justice., Journal of Business Ethics, 140, pp. 615-631.

Cugueró-Escofet, N. and Rosanas, J. M. (2016). The Ethics of Metrics: Overcoming the Dysfunctional Effects of Performance Measurements Through Justice, Journal of Business Ethics, 140, pp. 615-631.

Dahler-Larsen, P. (2014). Constitutive effects of performance indicators: Getting beyond unintended consequences, Public Management Review, 16, pp. 969-986.

Davis, J. H., Schoorman, F. D. and Donaldson, L. (1997a). Toward a Stewardship Theory of Management, Academy of Management Review, 22, pp. 20-47.

Davis, J., Schoorman, F. and Donaldson, L. (1997b). Toward a Stewardship Theory of Management, Academy of Management Review, 22, pp. 20-47.

Davis, S. and Albright, T. (2004). An investigation of the effect of Balanced Scorecard implementation on financial performance, Management Accounting Research, 15, pp. 135153.

de Zwart, F. (2015). Unintended but not unanticipated consequences, Theory and Society, 44, pp. 283-297.

Delbridge, R. and Fiss, P. C. (2013). Editors' Comments: Styles of theorizing and the social organization of knowledge, Academy of Management Review, 38, pp. 325-331.

Donaldson, L. (2001). The contingency theory of organizations. Thousand Oaks, CA: Sage Publications Ltd. 
Dossi, A. and Patelli, L. (2010). You learn from what you measure: Financial and nonfinancial performance measures in multinational companies, Long Range Planning, 43, pp. 498-526.

Doty, D. H. and Glick, W. H. (1994). Typologies as a unique form of theory building: Toward improved understanding and modeling, Academy of Management Review, 19, pp. 230-251.

Drazin, R. and Van de Ven, A. (1985). Alternative Forms of Fit in Contigency Theory, Administrative Science Quarterly, 30, pp. 514-539.

Eisenhardt, K. M. (1989). Agency theory: an assessment and review, Academy of Management Journal, 14, pp. 57-74.

Elias, N. (1997). Towards a theory of social processes: a translation, British Journal of Sociology, 48, pp. 355-383.

Elias, N. (1998). The Norbert Elias Reader, Goudsblom, J., Mennell, S., Jephcott, E., Krieken, R. van, Goudsblom, J., and Mennel, S. (Trans) (eds),. Malden: Blackwell Publishing.

Evans, J. H., Hanna, R. L., Krishnan, R. and Moser, D. V. (2001). Honesty in Managerial Reporting, The Accounting Review, 76, pp. 537-559.

Ferreira, A. and Otley, D. T. (2009). The design and use of performance management systems: An extended framework for analysis, Management Accounting Research, 20, pp. 263-282.

Flamholtz, E. G., Das, T. K. K. and Tsui, A. S. (1985). Toward an integrative framework of organizational control, Accounting, Organizations \& Society, 10, pp. 35-50.

Foucault, M. (1977). Discipline and punish: the birth of the prison. London, UK.: Penguin. Francis, R. (2013). Report of the Mid Staffordshire NHS Foundation Trust Public Inquiry. London, UK: The Stationery Office.

Franco-Santos, M. and Doherty, N. (2017). Performance management and well-being: a close look at the changing nature of the UK higher education workplace, International Journal of Human Resource Management, 28, pp. 2319-2350.

Franco-Santos, M., Lucianetti, L. and Bourne, M. (2012). Contemporary performance measurement systems: A review of their consequences and a framework for research, Management Accounting Research, 23, pp. 79-119.

Franco-Santos, M., Nalick, M., Rivera-Torres, P. and Gomez-Mejia, L. (2017). Governance and Well-being in Academia: Negative Consequences of Applying an Agency Theory Logic in Higher Education, British Journal of Management, 28, pp. 711-730.

Franco-Santos, M., Rivera, P. and Bourne, M. (2014). Performance management in UK Higher Education institutions. Leadership Foundation for Higher Education.

Frey, B. S., Homberg, F. and Osterloh, M. (2013). Organizational Control Systems and Payfor-Performance in the Public Service, Organization Studies, 34, pp. 949-972.

Godener, A. and Eric, K. (2004). Use and impact of performance measurement results in R \& D and NPD : an exploratory study, $R \& D$ Management, 2, pp. 191-219.

Gough, D. (2015). Qualitative and mixed methods in systematic reviews, Systematic Reviews, 4.

Gough, D., Thomas, J. and Oliver, S. (2012). Clarifying differences between review designs and methods, Systematic Reviews, 1.

Hall, M. (2011). Do comprehensive performance measurement systems help or hinder managers' mental model development?, Management Accounting Research, 22, pp. 68-83.

Hannan, R., Rankin, F. and Towry, K. (2006). The effect of information systems on honesty in managerial reporting: A behavioral perspective, Contemporary Accounting Research, 23, pp. 885-918.

Hansen, S. C., Otley, D. T. and Van der Stede, W. A. (2003). Practice Developments in 
Budgeting: An Overview and Research Perspective, Journal of Management Accounting Research, 15, pp. 95-116.

Harris, J. and Bromiley, P. (2007). Incentives to Cheat: The Influence of Executive Compensation and Firm Performance on Financial Misrepresentation., Organization Science, 18, pp. 350-367.

Healy, P. (1985). The effect of bonus schemes on accounting decisions, Journal of Accounting and Economics.

Hernandez, M. (2012). Toward an understanding of the psychology of stewardship, Academy of Management Review, 37, pp. 172-193.

Hood, C. (2006). Gaming in targetworld: The targets approach to managing british public services, Public Administration Review, 66, pp. 515-521.

Hopwood, A. G. (1972). An empirical study of the role of accounting data in performance evaluation, Journal of Accounting Research, 10, pp. 156-182.

Ittner, C. D., Larcker, D. F. and Randall, T. (2003). Performance implications of strategic performance measurement in financial services firms, Accounting, Organizations and Society, 28, pp. 715-741.

Jensen, M. C. (2003). Paying People to Lie: The Truth About the Budgeting Process, European Financial Management, 9, pp. 379-406.

Jensen, M. C. and Meckling, W. H. (1976). Theory of the firm: Managerial behavior, agency costs and ownership structure, Journal of Financial Economics, 3, pp. 305-360.

Kalgin, A. (2016). Implementation of Performance Management in Regional Government in Russia: Evidence of Data Manipulation, Public Management Review, 18, pp. 110-138.

Kerpershoek, E., Groenleer, M. and de Bruijn, H. (2016). Unintended responses to performance management in dutch hospital care: Bringing together the managerial and professional perspectives, Public Management Review, 18, pp. 417-436.

Kreutzer, M., Cardinal, L. B., Walter, J. and Lechner, C. (2016). Formal and Informal Control as Complement or Substitute? The Role of the Task Environment, Strategy Science, 1, pp. 235-255.

Kuhlmann, S., Bogumil, J. and Grohs, S. (2008). Evaluating Administrative Modernization in German Local Governments: Success or Failure of the 'New Steering Model'?, Public Administration Review, September, p. 851-863.

$\mathrm{Li}$, J. (2015). The paradox of performance regimes: Strategic responses to target regimes in Chinese local government, Public Administration, 93, pp. 1152-1167.

Lindsay, C., Osborne, S. P. and Bond, S. (2014). The 'new public governance' and employability services in an era of crisis: Challenges for third sector organizations in Scotland, Public Administration, 92, pp. 192-207.

Lowe, E. A. and Shaw, R. W. (1968). An Analysis of Managerial Biasing: Evidence From a Company'S Budgeting Process, Journal of Management Studies, 5, pp. 304-315.

Maas, V. S. and Van Rinsum, M. (2013). How Control System Design Influences Performance Misreporting, Journal of Accounting Research, 51, pp. 1159-1186.

Mackay, B. R. and Chia, R. (2013). Choice, chance and unintended consequences in strategic change: A process understanding of the rise and fall of Northco Automotive, Academy of Management Journal, 56, pp. 208-230.

Malmi, T. and Brown, D. A. (2008). Management control systems as a packageOpportunities, challenges and research directions, Management Accounting Research, 19, pp. 287-300.

Mannion, R. and Braithwaite, J. (2012). Unintended consequences of performance measurement in healthcare: 20 salutary lessons from the English National Health Service., Internal Medicine Journal, 42, pp. 569-74.

McAdam, R. and Bailie, B. (2002). Business performance measures and alignment impact on 
strategy: The role of business improvement models, International Journal of Operations \& Production Management, 22, pp. 972-996.

McCann, L., Granter, E., Hassard, J. and Hyde, P. (2015). 'You Can't Do Both-Something Will Give': Limitations of the Targets Culture in Managing UK Health Care Workforces., Human Resource Management, 54, pp. 773-791.

McGregor, D. (1960). The Human Side of Enterprise. New York, NY.: McGraw Hill.

Mckinley, W. and Scherer, A. G. (2000). Some unanticipated consequences of organizational restructuring, Academy of Management Review, 25, pp. 735-752.

Melnyk, S. A., Bititci, U., Platts, K., Tobias, J. and Andersen, B. (2014). Is performance measurement and management fit for the future?, Management Accounting Research, 25, pp. 173-186.

Mennell, S. (1977). 'Individual' action and its 'social' consequences in the work of Nobert Elias. InHuman Figurations. Amsterdams Sociologisch Tijdschrift, pp. 99-109.

Merchant, K. A. (1990). The effects of financial controls on data manipulation and management myopia, Accounting, Organizations and Society, 15, pp. 297-313.

Merton, R. K. (1936). The Unanticipated Consequences of Purposive Social Action, American Sociological Review, 1, pp. 894-904.

Merton, R. K. (1968). Social Theory and Social Structure. New York, NY.: Free Press.

Merton, R. K. (1996). On social structure and science. Chicago: University of Chicago Press.

Mica, A., Peisert, A. and Winczorek, J. (2011). Sociology and the unintended: Robert Merton Revisited. Peter Lang GmbH, Internationaler Verlag der Wissenschaften.

Miles, R. E. and Snow, C. C. (1978). Organization strategy, structure, and process. New York, NY.: McGraw-Hill.

Murphy, W. H. (2004). In pursuit of short-term goals: anticipating the unintended consequences of using special incentives to motivate the sales force., Journal of Business Research, 57, pp. 1265-1275.

Nilakant, V. and Rao, H. (1994). Agency Theory and Uncertainty in Organizations: An Evaluation, Organization Studies, 15, pp. 649-672.

Otley, D. (1999). Performance management: a framework for management control systems research, Management Accounting Research, 10, pp. 363-382.

Otley, D. (2016). The contingency theory of management accounting and control, Management Accounting Research, 31, pp. 45-62.

Otley, D., Broadbent, J. and Berry, A. (1995). Research in Management Control: An Overview of its Development., British Journal of Management, 6, pp. 31-44.

Otley, D. T. (1978). Budget use and managerial performance, Journal of Accounting Research, 16, pp. 122-149.

Otley, D. T. (1980). The contingency theory of management accounting: Achievement and prognosis, Accounting, Organizations and Society, 5, pp. 413-428.

Otley, D. T. and Berry, A. J. (1980). Control, organisation and accounting, Accounting, Organizations and Society, 5, pp. 231-244.

Otley, D. T. and Soin, K. (2015). Management control and uncertainty. Basingstoke: Palgrave Macmillan.

Ouchi, W. G. (1977). The relationship between organizational structure and organizational control, Administrative Science Quarterly, 22, pp. 95-113.

Ouchi, W. G. (1979). A conceptual framework for the design of organizational control mechanisms, Management Science, 25, pp. 833-848.

Ouchi, W. G. (1980). Markets, bureaucracies, and clans, Administrative Science Quarterly, 25, pp. 129-141.

Ouchi, W. G. and Johnson, J. B. (1978). Types of Organizational Control and Their Relationship to Emotional Well Being., Administrative Science Quarterly, 23, pp. 293-317. 
Parkinson, J. (2012). Managing Police Performance in England and Wales: Intended and Unintended Consequences. University of Cambridge.

Peattie, S., Peattie, K. and Newcombe, R. (2016). Unintended consequences in demarketing antisocial behaviour: project Bernie., Journal of Marketing Management, 32, pp. 15881618.

Perri, 6 (2014). Explaining unintended and unexpected consequences of policy decisions: Comparing three British Governments 1959-74, Public Administration, 92, pp. 673-691.

Portes, A. (2000). The hidden abode: sociology as analysis of the unexpected, American Sociological Review, 65, pp. 1-18.

Rankin, F., Schwartz, S. and Young, R. (2008). The effect of honesty and superior authority on budget proposals, The Accounting Review, 83, pp. 1083-1099.

Ridgway, V. F. (1956). Dysfunctional consequences of performance measurements, Administrative Science Quarterly, 1, pp. 240-247.

Ridley, D. (2012). The literature review: A step-by-step guide for students. London, UK.: Sage Publications Ltd.

Salterio, S. E. and Webb, A. (2006). Honesty in accounting and control: A discussion of 'the effect of information systems on honesty in managerial reporting: A behavioural perspective', Contemporary Accounting Research, 23, pp. 919-932.

Schiff, M. and Lewin, A. Y. (1970). The impact of people on budgets, Accounting Review, 45, pp. 259.

Schwepker, C. H. and Good, D. J. (2012). Sales Quotas: Unintended Consequences on Trust in Organization, Customer-Oriented Selling, and Sales Performance, Journal of Marketing Theory \& Practice, 20, pp. 437-452.

Segal, L. and Lehrer, M. (2012). The Institutionalization of Stewardship: Theory, Propositions, and Insights from Change in the Edmonton Public Schools, Organization Studies, 33, pp. 169-201.

Shepherd, D. A. and Suddaby, R. (2017). Theory building: A review and integration, Journal of Management, 43, pp. 59-86.

Smith, A. (1759). The theory of moral sentiments. printed for A. Millar; and A. Kincaid and J. Bell, in Edinburgh.

Smith, M. and Bititci, U. (2017). Interplay between performance measurement and management, employee engagement and performance, International Journal of Operations and Production Management, 37, pp. 1207-1228.

Smith, P. (1995a). On the unintended consequences of publishing performance data in the public sector, International Journal of Public Administration, 18, pp. 277-310.

Smith, P. (1995b). Performance indicators and outcome in the public sector, Public Money \& Management, 15, pp. 13-16.

Snow, C. C. and Ketchen David J., J. (2014). Typology-Driven Theorizing: A Response to Delbridge and Fiss., Academy of Management Review, 39, pp. 231-233.

Tan, K. H. and Rae, R. H. (2009). Uncovering the links between regulation and performance measurement, International Journal of Production Economics, 122, pp. 449-457.

Tranfield, D., Denyer, D. and Smart, P. (2003). Towards a methodology for developing evidence-informed management knowledge by means of systematic review, British Journal of Management, 14, pp. 207-222.

Waddington, I. (2016). Theorising unintended consequences of anti-doping policy, Performance Enhancement \& Health, 4, pp. 80-87.

Weick, E. (1989). Theory construction as disciplined imagination, Academy of Management Review, 14, pp. 516-531.

Weick, K. E. (1976). Educational organizations as loosely coupled systems, Administrative Science Quarterly, 21, pp. 1-19. 
Table 1. Literature review mixed methods overview

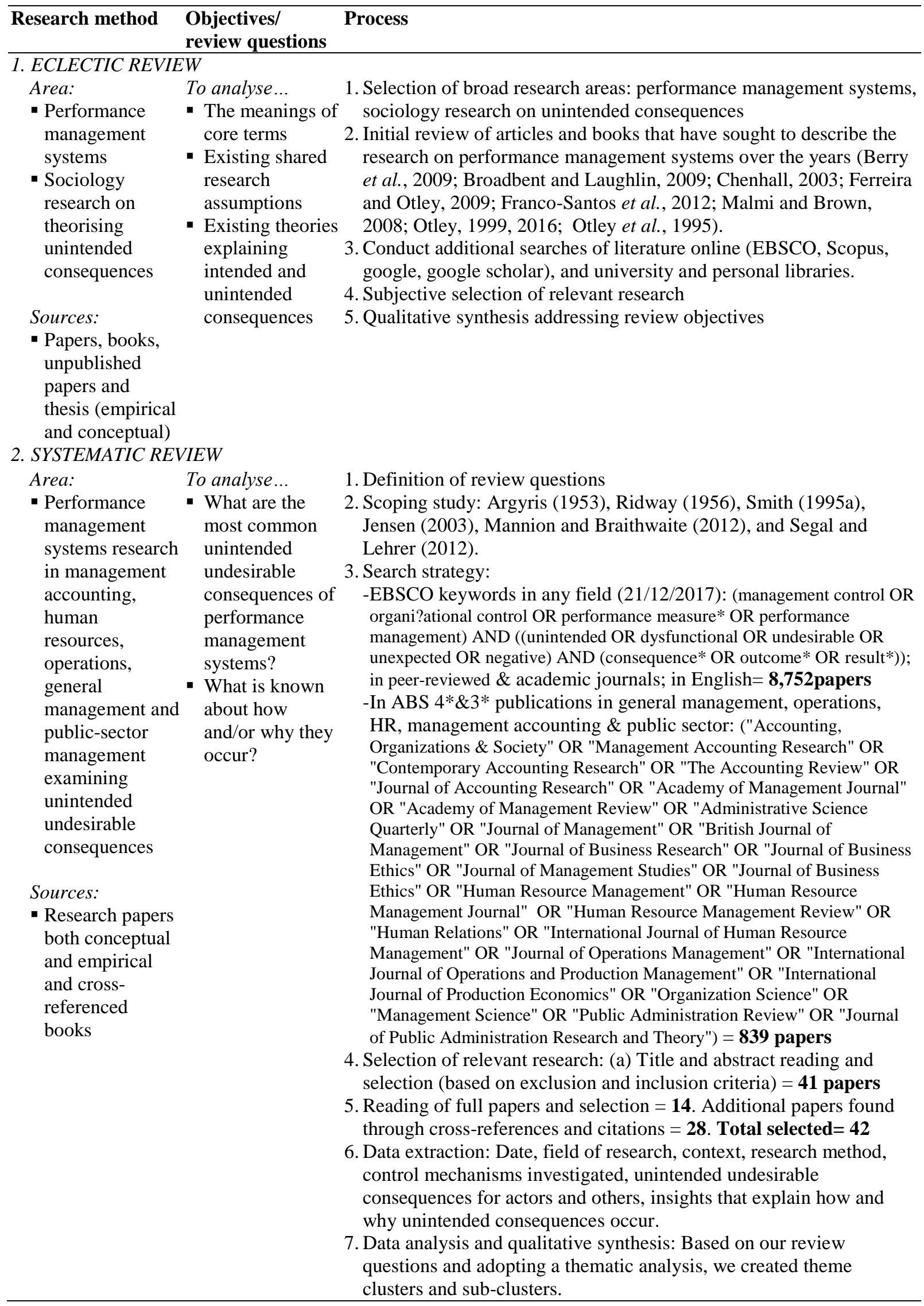


Table 2. An overview of the unintended undesirable consequences of performance management systems

\begin{tabular}{|c|c|c|c|c|c|c|c|}
\hline \multirow{2}{*}{ Authors } & \multirow[t]{2}{*}{ Date } & \multirow[t]{2}{*}{ Field $^{7}$} & \multirow{2}{*}{$\begin{array}{l}\text { Context \& } \\
\text { method }\end{array}$} & \multicolumn{3}{|c|}{ Control mechanisms Unintended consequences } & \multirow{2}{*}{$\begin{array}{l}\text { Insights that explain how and why unintended } \\
\text { consequences occur }\end{array}$} \\
\hline & & & & investigated & For actors & $\begin{array}{l}\text { For others - } \\
\text { external } \\
\text { stakeholders }\end{array}$ & \\
\hline $\begin{array}{l}\text { Agyemang, } \\
\text { Broadbent }\end{array}$ & $(2015)$ & ACC & $\begin{array}{l}\text { Public sector } \\
\text { (Higher } \\
\text { Education- } \\
\text { REF process, } \\
\text { UK); } \\
\text { Conceptual/ } \\
\text { literature review }\end{array}$ & $\begin{array}{l}\text { Directive: } \\
\text { - Performance } \\
\text { planning, } \\
\text { measurement, targets. } \\
\text { Enabling } \\
\text { - Professional and } \\
\text { collegial values and } \\
\text { standards }\end{array}$ & $\begin{array}{l}\text { Directive } \\
\text { - Movement away from previously } \\
\text { held academic values } \\
\text { - Resistance to external regulatory } \\
\text { systems originating controls that are } \\
\text { more restrictive than the systems they } \\
\text { are meant to resist } \\
\text { - Gaming } \\
\text { - Symbolic violence }\end{array}$ & $\begin{array}{r}\text { Dysfunctional } \\
\text { consequences } \\
\text { for academics }\end{array}$ & $\begin{array}{l}\text { - Due to commensuration reactions and self-fulfilling } \\
\text { prophecy the inner working of organisations change. } \\
\text { These reorientation changes, over time produce other } \\
\text { changes in deeply held values, which ultimately affect } \\
\text { individual behaviour. The gaming that comes with the } \\
\text { reorientation processes ends up generating } \\
\text { dysfunctional consequences for individuals. Symbolic } \\
\text { violence (Bourdieu, 1977) is used to explain the } \\
\text { change process. }\end{array}$ \\
\hline Argyris & $(1953) *^{8}$ & GM & $\begin{array}{l}\text { For profit } \\
\text { (Manufacturing, } \\
\text { US); Case } \\
\text { studies }\end{array}$ & $\begin{array}{l}\text { Directive: } \\
\text { - Performance } \\
\text { measurement, targets, } \\
\text { review (budgets) }\end{array}$ & $\begin{array}{l}\text { - Grouping: employees 'against' } \\
\text { management } \\
\text { - Blame culture } \\
\text { - Social relations problems (e.g., } \\
\text { tensions and conflicts among } \\
\text { departments and against budget } \\
\text { setters) } \\
\text { - Internalized pressure of line } \\
\text { managers resulting in overwork, } \\
\text { stress, increase monitoring of } \\
\text { employees, frustration, unhappiness } \\
\text { - Self-interest and silo-mentality } \\
\text { - Patterns of leadership (focus on the } \\
\text { numbers rather than people) } \\
\text { - Illusion of control (implied) }\end{array}$ & - No reference & $\begin{array}{l}\text { - Increase pressure leads to dysfunctions } \\
\text { - Argyris mentions the use of budgets is based on the } \\
\text { believe that people do not want to work unless they } \\
\text { are pushed/controlled which may not always be a } \\
\text { valid assumption. }\end{array}$ \\
\hline Ashton & $\begin{array}{l}\text { (Ashton, } \\
1976)\end{array}$ & ACC & $\begin{array}{l}\text { Various } \\
\text { contexts; } \\
\text { Conceptual }\end{array}$ & $\begin{array}{l}\text { Directive: } \\
\text { - Performance } \\
\text { planning, }\end{array}$ & $\begin{array}{l}\text { - Interpersonal tensions } \\
\text { - Felt need of defensibility of } \\
\text { individual action } \\
\text { - Rigidity of behaviour }\end{array}$ & - No reference & $\begin{array}{l}\text { - Controller's preconceptions about the abilities and } \\
\text { motivations of the people being controlled are } \\
\text { reinforced by the control system. The result is mutual } \\
\text { deception rather than learning. A circle develops in }\end{array}$ \\
\hline
\end{tabular}

${ }^{7}$ Data field designated using abbreviations: Accounting (ACC), Human resources (HR), General management (GM), Public sector management (PSM), Operations (OP)

${ }^{8}$ Studies with $*$ indicate that they were selected for the scoping study. 


\begin{tabular}{|c|c|c|c|c|c|c|c|}
\hline \multirow[t]{2}{*}{ Authors } & \multirow[t]{2}{*}{ Date } & \multirow[t]{2}{*}{ Field $^{7}$} & \multirow[t]{2}{*}{$\begin{array}{l}\text { Context \& } \\
\text { method }\end{array}$} & $\begin{array}{l}\text { Control mechanisms } \\
\text { investigated }\end{array}$ & $\begin{array}{l}\text { Unintended consequences } \\
\text { For actors }\end{array}$ & $\begin{array}{l}\text { For others - } \\
\text { external } \\
\text { stakeholders } \\
\end{array}$ & $\begin{array}{l}\text { Insights that explain how and why unintended } \\
\text { consequences occur }\end{array}$ \\
\hline & & & & $\begin{array}{l}\text { measurement, targets } \\
\text { (budgets). }\end{array}$ & $\begin{array}{l}\text { - Use of trappings of authority } \\
\text { - Difficulty with clients } \\
\text { - Bifurcation of interests } \\
\text { - Conflicts among organizational sub- } \\
\text { units } \\
\text { - Illusion of control } \\
\text { - Differences between organizational } \\
\text { goals and achievement }\end{array}$ & & $\begin{array}{l}\text { which each's misconception about the other is } \\
\text { reinforced, potentially leading to perverse } \\
\text { consequences. } \\
\text { - Time is crucial for understanding overall } \\
\text { consequences (i.e., beneficial short-term outcomes } \\
\text { may turn to be dysfunctional over time due to } \\
\text { deviation amplifying feedback). } \\
\text { - Interventions can be conducted to change loops from } \\
\text { dysfunctional to functional. These interventions } \\
\text { operate by changing the pattern of relationships. } \\
\text { Relationships, not people, are the critical control } \\
\text { points in organizations. }\end{array}$ \\
\hline Berliner & (1956) & GM & $\begin{array}{l}\text { Public sector/ } \\
\text { State enterprises } \\
\text { (Production, } \\
\text { Russia); } \\
\text { Interviews and } \\
\text { archival data }\end{array}$ & $\begin{array}{l}\text { Directive: } \\
\text { - Performance } \\
\text { planning, } \\
\text { measurement, targets } \\
\text { (budgets), } \\
\text { performance-based } \\
\text { rewards (individual } \\
\text { incentive pay, } \\
\text { promotions, } \\
\text { sanctions) }\end{array}$ & $\begin{array}{l}\text { - Gaming (storming) - Although side } \\
\text { negative effects will exist, these are } \\
\text { perceived to be a "price worth } \\
\text { paying" for the benefits obtained in } \\
\text { terms of managerial effort }\end{array}$ & - No reference & $\begin{array}{l}\text { - The combination of production planning, measures, } \\
\text { targets and incentives lead to motivational and } \\
\text { behavioural responses from managers (ratchet } \\
\text { principle) which are dysfunctional } \\
\text { - High complexity and uncertainty of state enterprises } \\
\text { (implied) } \\
\text { - Agency theory related assumptions } \\
\text { - Continuous change (in managers) }\end{array}$ \\
\hline $\begin{array}{l}\text { Bonner \& } \\
\text { Sprinkle }\end{array}$ & $(2002)$ & $\mathrm{ACC}$ & $\begin{array}{l}\text { Various } \\
\text { contexts; } \\
\text { Literature } \\
\text { review }\end{array}$ & $\begin{array}{l}\text { Directive: } \\
\text { - Performance-based } \\
\text { rewards (individual } \\
\text { incentive pay }\end{array}$ & $\begin{array}{l}\text { Employee well-being (Anxiety, } \\
\text { affect, stress) }\end{array}$ & - No reference & $\begin{array}{l}\text { - Unintended consequences due to increased pressure to } \\
\text { perform. }\end{array}$ \\
\hline \multicolumn{2}{|c|}{$\begin{array}{l}\text { Cardinaels \& (2015) } \\
\text { Yin }\end{array}$} & $\mathrm{ACC}$ & $\begin{array}{l}\text { Management } \\
\text { students; } \\
\text { Experiment }\end{array}$ & $\begin{array}{l}\text { Directive: } \\
\text { - Performance } \\
\text { measurement, targets } \\
\text { (budgets), } \\
\text { Performance-based } \\
\text { rewards (individual } \\
\text { incentive pay vs. } \\
\text { fixed-salary) }\end{array}$ & $\begin{array}{l}\text { - Employees' dishonesty and } \\
\text { misreporting } \\
\text { - Distrust } \\
\text { - Crowding out pro-social motivations }\end{array}$ & - No reference & $\begin{array}{l}\text { - Principals with their choice of controls (incentive pay } \\
\text { vs higher fixed pay) leak information to agents about } \\
\text { what the principals have observed of other agents. The } \\
\text { choice of fixed wage contracts implies that the } \\
\text { principal believes agents have an inherent motive to } \\
\text { be honest (i.e., they are not opportunistic or self- } \\
\text { interested). The choice of incentive contracts sends a } \\
\text { message of distrust as it implies the principal assumes } \\
\text { agents are likely to be opportunistic and, if not } \\
\text { controlled, they will misreport. }\end{array}$ \\
\hline
\end{tabular}




\begin{tabular}{|c|c|c|c|c|c|c|c|}
\hline Authors & Date & Field $^{7}$ & $\begin{array}{l}\text { Context \& } \\
\text { method }\end{array}$ & $\begin{array}{l}\text { Control mechanisms } \\
\text { investigated }\end{array}$ & $\begin{array}{l}\text { Unintended consequences } \\
\text { For actors }\end{array}$ & $\begin{array}{l}\text { For others - } \\
\text { external } \\
\text { stakeholders }\end{array}$ & $\begin{array}{l}\text { Insights that explain how and why unintended } \\
\text { consequences occur }\end{array}$ \\
\hline & & & & & & & $\begin{array}{l}\text { - Most importantly, the decision to introduce incentive } \\
\text { contracts may lead an employee to believe that other } \\
\text { employees in the organization are behaving } \\
\text { opportunistically, which in turn can affect his/her own } \\
\text { behaviour. } \\
\text { - A belief suggesting that employees in general are } \\
\text { opportunistic, changes social norms. Over time, } \\
\text { people conform to this norm, increasing their } \\
\text { opportunistic/self-interested behaviour and } \\
\text { misreporting. }\end{array}$ \\
\hline Carmichael & (1970) & ACC & $\begin{array}{l}\text { Various } \\
\text { contexts; } \\
\text { Conceptual }\end{array}$ & $\begin{array}{l}\text { Directive: } \\
\text { - Performance } \\
\text { planning, } \\
\text { measurement, targets } \\
\text { (budgets). }\end{array}$ & $\begin{array}{l}\text { - Measure fixation } \\
\text { - Gaming } \\
\text { - Dishonesty } \\
\text { - Misrepresentation } \\
\text { - Implied (relationship problems } \\
\text { between management and } \\
\text { employees) }\end{array}$ & - No reference & $\begin{array}{l}\text { - The assumptions made about people in organizations } \\
\text { operate as a theory which determines how employees } \\
\text { will be treated. If control designers believe that } \\
\text { employees have inherent mental, moral, and physical } \\
\text { weaknesses so they need internal controls to achieve } \\
\text { organizational goals; this assumption tends to be self- } \\
\text { fulfilling: Employees may retaliate by exhibiting the } \\
\text { behaviour the system was intended to control. Thus, a } \\
\text { perfect "control" system may stimulate violation of } \\
\text { control procedures. } \\
\text { - Non-compliance tends to appear in the presence of } \\
\text { perceived thread (e.g., application of punitive } \\
\text { measures when targets are not met, pressure for higher } \\
\text { performance, the concept of accountability). }\end{array}$ \\
\hline $\begin{array}{l}\text { Chow, } \\
\text { Cooper \& } \\
\text { Waller }\end{array}$ & (1988) & ACC & $\begin{array}{l}\text { Students; } \\
\text { Experiment }\end{array}$ & $\begin{array}{l}\text { Directive: } \\
\text { - Performance } \\
\text { measurement, targets, } \\
\text { review (budgets), } \\
\text { performance-based } \\
\text { rewards (individual } \\
\text { incentive pay) }\end{array}$ & $\begin{array}{l}\text { - Misrepresentation of financial } \\
\text { information or 'slack' }\end{array}$ & - No reference & $\begin{array}{l}\text { - Design issues lead to unintended undesirable } \\
\text { consequences. Better designs reduce these } \\
\text { consequences. }\end{array}$ \\
\hline
\end{tabular}




\begin{tabular}{|c|c|c|c|c|c|c|c|}
\hline Authors & Date & Field $^{7}$ & $\begin{array}{l}\text { Context \& } \\
\text { method }\end{array}$ & $\begin{array}{l}\text { Control mechanisms } \\
\text { investigated }\end{array}$ & $\begin{array}{l}\text { Unintended consequences } \\
\text { For actors }\end{array}$ & $\begin{array}{l}\text { For others - } \\
\text { external } \\
\text { stakeholders }\end{array}$ & $\begin{array}{l}\text { Insights that explain how and why unintended } \\
\text { consequences occur }\end{array}$ \\
\hline $\begin{array}{l}\text { Chow, Kato, } \\
\text { Merchant }\end{array}$ & (1996) & ACC & $\begin{array}{l}\text { Manufacturing } \\
\text { (profit centres, } \\
\text { US and Japan); } \\
\text { Interviews and } \\
\text { survey }\end{array}$ & $\begin{array}{l}\text { Directive: } \\
\text { - Performance } \\
\text { measurement and } \\
\text { targets, process } \\
\text { controls, directives in } \\
\text { formal meetings, } \\
\text { headcount controls }\end{array}$ & $\begin{array}{l}\text { - Data manipulation } \\
\text { - Management myopia (short-termism) }\end{array}$ & - No reference & $\begin{array}{l}\text { - Different cultural conditions (values \& beliefs)- } \\
\text { Japanese under equally tight controls (although not } \\
\text { the same controls) respond with less dysfunctional } \\
\text { consequences. }\end{array}$ \\
\hline Chwastiak & (2006) & ACC & $\begin{array}{l}\text { Public sector } \\
\text { (Vietnam war, } \\
\text { US perspective); } \\
\text { Content analysis } \\
\text { of archival } \\
\text { information. }\end{array}$ & $\begin{array}{l}\text { Directive: } \\
\text { - Performance } \\
\text { planning, } \\
\text { performance } \\
\text { measures and targets, } \\
\text { reviews, performance } \\
\text { related rewards }\end{array}$ & $\begin{array}{l}\text { - Gaming } \\
\text { - Misrepresentation } \\
\text { - Selective attention (visibility of what } \\
\text { can be measured, invisibility of what } \\
\text { cannot be measured) } \\
\text { - Restricting political change } \\
\text { (numbers, not people, as responsible } \\
\text { for decisions) } \\
\text { - Illusion of control }\end{array}$ & $\begin{array}{l}\text { - Perverse } \\
\text { results for } \\
\text { civilians }\end{array}$ & $\begin{array}{l}\text { - The performance management system (PPB) } \\
\text { introduced a new discourse that equated truth focused } \\
\text { on the things that could be counted. Less tangible } \\
\text { aspects became invisible. Over time, this } \\
\text { "instrumental rationality' dismissed as irrational } \\
\text { decision making based on intuition and morality. } \\
\text { Meanings were lost and the focused moved from } \\
\text { human actors to structural and technical defence } \\
\text { issues. This process led to the belief that "every } \\
\text { problem could be managed" which affected leadership } \\
\text { perceptions and behaviours. }\end{array}$ \\
\hline $\begin{array}{l}\text { Conrad \& } \\
\text { Guven Uslu }\end{array}$ & (2012) & $\mathrm{ACC}$ & $\begin{array}{l}\text { Public sector } \\
\text { (NHS hospital, } \\
\text { UK); Case study }\end{array}$ & $\begin{array}{l}\text { Directive: } \\
\text { - Performance } \\
\text { planning, } \\
\text { performance } \\
\text { measures and targets, } \\
\text { performance reviews }\end{array}$ & $\begin{array}{l}\text { - Gaming } \\
\text { - Short-termism }\end{array}$ & $\begin{array}{l}\text { - Increase } \\
\text { mortality } \\
\text { - Decrease } \\
\text { quality of care }\end{array}$ & $\begin{array}{l}\text { - Adoption of private-sector like practices in a context } \\
\text { where these practices do not apply (different } \\
\text { rationalities) } \\
\text { - Lack of control of factors affecting performance }\end{array}$ \\
\hline Cox & (2005) & HR & $\begin{array}{l}\text { For profit } \\
\text { (Engineering } \\
\text { SMEs, UK); } \\
\text { Case studies }\end{array}$ & $\begin{array}{l}\text { Directive: } \\
\text { - Performance } \\
\quad \text { evaluation and } \\
\text { performance-based } \\
\text { rewards (individual } \\
\text { incentive pay) }\end{array}$ & $\begin{array}{l}\text { - Disrupted production } \\
\text { - Administrative overload and } \\
\text { managerial time costs } \\
\text { - Damaging social relationships }\end{array}$ & - No reference & $\begin{array}{l}\text { - Increase pressure leads to dysfunctions } \\
\text { - Environmental complexity }\end{array}$ \\
\hline $\begin{array}{l}\text { Cuguero- } \\
\text { Escofet \& } \\
\text { Rosanas }\end{array}$ & (2017) & GM & $\begin{array}{l}\text { For profit } \\
\text { (Banking, } \\
\text { Fashion, High } \\
\text { Tech, Spain); } \\
\text { Case studies }\end{array}$ & $\begin{array}{l}\text { Directive: } \\
\text { - Performance } \\
\text { measurement, targets, } \\
\text { reviews, } \\
\text { performance-based } \\
\text { rewards (individual } \\
\text { incentive pay) }\end{array}$ & $\begin{array}{l}\text { - Gaming (metrics "pushing" people in } \\
\text { the wrong direction) } \\
\text { - Data manipulation } \\
\text { - Double injustice (ethical dilemmas \& } \\
\text { then unfair rewards) } \\
\text { - Misreporting }\end{array}$ & $\begin{array}{l}\text { Risk } \\
\text { transferred to } \\
\text { customers - } \\
\text { Banking case } \\
\text { (implied from } \\
\text { text) }\end{array}$ & $\begin{array}{l}\text { - Increase pressure leads to dysfunctions } \\
\text { - Organizational complexity that cannot be reflected in } \\
\text { metrics. }\end{array}$ \\
\hline
\end{tabular}




\begin{tabular}{|c|c|c|c|c|c|c|c|}
\hline Authors & Date & Field $^{7}$ & $\begin{array}{l}\text { Context \& } \\
\text { method }\end{array}$ & $\begin{array}{l}\text { Control mechanisms } \\
\text { investigated }\end{array}$ & $\begin{array}{l}\text { Unintended consequences } \\
\text { For actors }\end{array}$ & $\begin{array}{l}\text { For others - } \\
\text { external } \\
\text { stakeholders } \\
\end{array}$ & $\begin{array}{l}\text { Insights that explain how and why unintended } \\
\text { consequences occur }\end{array}$ \\
\hline & & & & & $\begin{array}{l}\text { - Mission/Strategy drift (revisions } \\
\text { based on what can be counted rather } \\
\text { than what is relevant) } \\
\text { - Measure fixation (people focused on } \\
\text { the measured and ignored what was } \\
\text { not measured) } \\
\text { - Illusion of control }\end{array}$ & & \\
\hline $\begin{array}{l}\text { Evans, } \\
\text { Hannan, } \\
\text { Krishnan \& } \\
\text { Moser }\end{array}$ & (2001) & $\mathrm{ACC}$ & $\begin{array}{l}\text { Students } \\
\text { (Management } \\
\text { school, US); } \\
\text { Experiments }\end{array}$ & $\begin{array}{l}\text { Directive: } \\
\text { - Performance } \\
\text { measurement, targets, } \\
\text { review (budgets), } \\
\text { performance-based } \\
\text { rewards (individual } \\
\text { incentive pay and } \\
\text { profit-sharing) }\end{array}$ & - Dishonesty & - No reference & $\begin{array}{l}\text { - Agency theory assumes that people have a low } \\
\text { threshold for dishonesty; they will lie for little } \\
\text { payoffs. However, this research shows that people are } \\
\text { considerably honest } \\
\text { - The degree of dishonesty or misrepresentation of } \\
\text { financial information is dependent on the type of } \\
\text { contract used: less sharing of wealth between } \\
\text { organization and employees; more dishonesty. Fixed } \\
\text { salary and profit-sharing prompt more honest } \\
\text { reporting. Performance related pay leads to more } \\
\text { dishonesty. } \\
\text { - People care about more things that just wealth; they } \\
\text { care about equity and reciprocity. }\end{array}$ \\
\hline $\begin{array}{l}\text { Franco- } \\
\text { Santos, } \\
\text { Nalick, } \\
\text { Rivera- } \\
\text { Torres, \& } \\
\text { Gomez- } \\
\text { Mejia }\end{array}$ & (2017) & GM & $\begin{array}{l}\text { Public sector } \\
\text { (Higher } \\
\text { Education, UK); } \\
\text { Survey }\end{array}$ & $\begin{array}{l}\text { Directive: } \\
\text { - Performance } \\
\text { planning, } \\
\text { performance } \\
\text { measures and targets, } \\
\text { performance reviews } \\
\text { Enabling (Collegial): } \\
\text { - Consultation, } \\
\text { communication, } \\
\text { provision of needed } \\
\text { job resources, } \\
\text { comprehensive } \\
\text { performance } \\
\text { recognition, focus on } \\
\text { development, } \\
\text { autonomy }\end{array}$ & $\begin{array}{l}\text { Directive: } \\
\text { - Decreased well-being (for } \\
\text { academics) }\end{array}$ & $\begin{array}{l}\text { - Decreased } \\
\text { benefits for } \\
\text { students, } \\
\text { science and } \\
\text { society at large } \\
\text { (not measured) }\end{array}$ & $\begin{array}{l}\text { - Wrong assumptions about academics' motivations and } \\
\text { the context of academia leading to directive controls } \\
\text { which affect well-being and, over time, would have } \\
\text { negative effects on motivation, behaviours and social } \\
\text { relationships leading to further unintended } \\
\text { consequences not just for academics but also for } \\
\text { others. } \\
\text { - Complexity of academic work }\end{array}$ \\
\hline
\end{tabular}




\begin{tabular}{|c|c|c|c|c|}
\hline Authors & Date & Field $^{7}$ & $\begin{array}{l}\text { Context \& } \\
\text { method }\end{array}$ & $\begin{array}{l}\text { Control mechanisms Unintended consequences } \\
\text { investigated }\end{array}$ \\
\hline $\begin{array}{l}\text { Hannan, } \\
\text { Rankin \& } \\
\text { Towry }\end{array}$ & (2006) & ACC & $\begin{array}{l}\text { Students } \\
\text { (Management, } \\
\text { US); Experiment }\end{array}$ & $\begin{array}{l}\text { Directive: } \\
\text { - Performance } \\
\text { measurement, targets, } \\
\text { review (budget), } \\
\text { performance-based } \\
\text { rewards (individual } \\
\text { incentive pay }\end{array}$ \\
\hline
\end{tabular}

Insights that explain how and why unintended

For others - consequences occur

external

stakeholders

- No reference - The research assumes managers (agents) are

opportunistic (misaligned goals). They may

misrepresent private information in order to maximize their own self-interest.

- Using a measurement/information system influences the ability of an agent to appear honest. It gives the principal a signal about the agent's private information. By comparing this signal to the managers' report, the principal can form an impression of the agent's honesty.

- Misrepresentation of financial information depends on the design choices of the measurement/information

system

- The use of an information system (vs the no use) enhances honesty. A precise system is associated to a higher level of honesty than a coarse system.

- An assumption in this research is that the agent cannot manipulate the measurement/information system.

Harris \&

(2007)

GM

For profit sector Directive:

(Financial - Performance

restatements measures, targets,

with accounting review, performance

irregularities, related rewards

US)

(incentive pay)

Hasen,

Otley, Van

(2003)

der Stede non-for-profit - Performance

sectors;
- Corporate misconduct: Financial misrepresentation

\section{- Mentioned} negative

consequences for society and social

progress, but

not measured

- No reference

Constrain responsiveness and are measurement, targets, often a barrier to change

Literature review (budgets)

- Strengthen vertical command-andcontrol

- Miss out on emerging network structures

- Encourage gaming and perverse behaviours

- Reinforce department barriers rather than encourage knowledge sharing

- Make people feel undervalued
- Building on the behavioural theory of the firm, it is argued that misrepresentation is caused by the use of strong incentive compensation and poor financial performance compared to expectations. This argument is supported empirically.

- Design issues. Better designs that improve the budgeting process (activity-based budgeting approach) or abandon it (beyond budgeting) reduce unintended undesirable consequences. 


\begin{tabular}{lllll}
\hline Authors & Date & Field $^{7}$ & $\begin{array}{l}\text { Context \& } \\
\text { method }\end{array}$ & $\begin{array}{l}\text { Control mechanisms Unintended consequences } \\
\text { investigated }\end{array}$
\end{tabular}

\section{For profit sector Directive:}

(Multiple

- Performance-based

industries, US); rewards (individual

Archival incentive pay)

Hood

PSM

Public sector
(Various

(Various

Literature

review and

interviews

Directive:

- Performance

measurement, targetand-terror regime,

performance

benchmarks
ACC For profit sector Directive:

(Manufacturing - Performance

Departments, evaluation (of

US); Survey and budgets)

interviews
- Gaming (earnings management-e.g., - No reference "taking a bath")

- Gaming or strategic behaviour (ratchet effect, threshold effect, output distortion

- Manipulation of data (cheating)

- Bulling and blame culture

- Eagerness of central managers to

accept "good news"

- Implied illusion of control

- Job related tensions

- Less favourable relationships with peers, distrust and rivalry, lack of cooperation

- Short-term orientation

- Data manipulation

- Illusion of control (false measure of

'cognitive simplicity')
- Decreased benefits for the public/society (implicit in

text)

(n)

- Bonus plans incentivize managers to select accounting techniques that enhance the value of their bonus payments. It is implied that this relationship occurs because managers are self-interested; the use of bonus plans that use accounting measures does not limit their opportunisms, it actually enhances it as they can manipulate these measures.

- Not explicitly stated explanation. However, at the end of the article, it is mentioned that most of the measures taken to decrease gaming were based on a low-trust approach that aimed to improve the design of the measurement system (tighter definitions, targets refinement, audit investigations, penalties, etc.). These practices reinforced

- Different approaches to the use of directive mechanisms (budget constrained style, profit conscious)

- Problems with the design of accounting measures (incompleteness, high complexity - lack of precision knowledge of the organization's economic cost function, sole focus on outcomes, focus on short-term financial performance, the cost of providing relevant data, multiple purposes)

- Hopwood argues that "accounting data do not in of themselves pose a threat to members of an organization" (p.174). The severity of unintended consequences depends on the way in which the data is used by managers (with the Budget constraints style creating serious concerns).

- The budget constraints style assumes the need to control individuals by evaluating their performance 


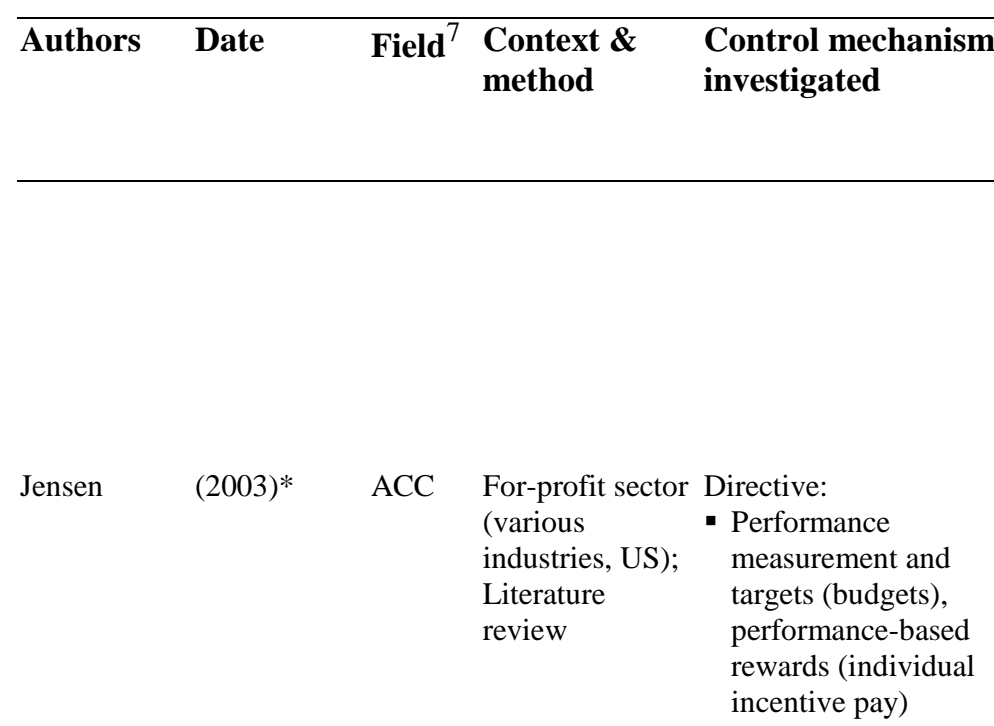

- Lying (misrepresentation)

- Gaming (e.g., sale products to entities

that had not ordered them, move

revenues from one quarter to the

previous quarter by backdating sales agreements, entered into secret side

agreements with clients, etc.)

- Destroy value for organizations

- Illusion of control

\begin{tabular}{|c|c|c|c|c|c|}
\hline Kalgin & (2016) & PSM & $\begin{array}{l}\text { Public sector } \\
\text { (Various } \\
\text { agencies, } \\
\text { Russia); } \\
\text { Interviews and } \\
\text { archival data }\end{array}$ & $\begin{array}{l}\text { Directive: } \\
\text { - Performance } \\
\text { planning, } \\
\text { performance } \\
\text { measures, targets, } \\
\text { performance reviews } \\
\text { including ranking } \\
\text { system }\end{array}$ & $\begin{array}{l}\text { - Misrepresentation } \\
\text { - Data manipulation (prudent and } \\
\text { reckless) } \\
\text { - Differences between measured } \\
\text { performance and actual performance }\end{array}$ \\
\hline
\end{tabular}

Insights that explain how and why unintended

For others - consequences occur

external

stakeholders

rather than interpreting the evaluation process as an ongoing activity of organizational learning. It

becomes the primary source of control and motivation becoming a constraint rather than a problem-solving mechanism. It imposes a "false measure of cognitive simplicity onto a complex and highly interdependent series of activities" (p. 175).

- No reference - Relating pay and promotions to performance targets leads to gaming and lying, which is disastrous for organizations

- Budget systems assume that managers should be rewarded for meeting targets and punish if they don't. Because of this, managers will have incentives to set easy targets, and do whatever it takes to meet them (even if their actions destroy value for the company).

- Gaming is inevitable, it is part of business life.

- Jensen assumes that managers are self-interested. Once a budget-target reward system is in operation, managers have no interest in providing accurate information in their budgets. This leads to critical information being hidden and chaotic actions leading to dysfunctionalities. Honesty and integrity are eroded. "Managing the numbers" is considered a part of management and these gaming behaviours become undiscussable.

- Decreased - The dysfunctionalities of unintended consequences benefits for the can be observable and theoretically predicted. public/ society - Initially, the study draws on agency theory ideas to (implicit in explain misrepresentation, suggesting that misrepresentation occurs due to information asymmetry and self-interested assumptions. However, the results suggest that this model does not operate in the Russian public-sector context.

- The Russian public-sector context is characterized by: negativity bias, blame avoidance and attention aversion. The behaviour of individuals working in this sector appears to reflect that of the 'administrative 
Insights that explain how and why unintended

\section{For others - consequences occur}

external

stakeholders

Kerpershoek, (Kerpershoe PSM Groenleer \& k et al., de Bruijn 2016)
Public sector (Health care, The Netherlands); Interviews
Directive:

- Performance

planning,

performance

measures and targets, - Strategic selection of expedient cases

performance reviews, (or 'cherry picking')

performance-related

rewards (incentive

pay)
- Misrepresentation of data (or 'up- - Negative coding') leading to misrepresentation outcomes for and suboptimal allocation of patients' care

man' model rather than the agency theory's

'economic man' model.

- Prudent misrepresentation emerged in intelligent regimes (measurement system without targets and rankings). This type of behaviour was driven by

individuals' need for security and convenience (i.e., to minimize attention). Prudent manipulated data are

inconspicuous to supervising authorities. If no audit is done, the validity of the data for decision making is undermined. However, it may be that the ultimate purpose of the Russian government is to have a 'meaningless system' overloaded with data. This system will reflect Foucault's (1977) 'bureaucratic panopticon', creating a normalizing effect. The importance is not the quality of data, but the

conformity and power that the system provides.

- Reckless manipulation was driven by the pressure generated by the use of systems including measures, targets and rankings.

- The justification for a new performance management system was driven by an agency theory rationale. However, the agency theory explanation of unintended consequences (self-interest, opportunism) is incomplete. Consideration of both financial and professional motives is required to understand the complex nature of this phenomenon.

- Unintended consequences are related to design issues (the link of measures to rewards and sanctions; a high financial impact) and the level of professionalism (specialized knowledge and competences).

- Medical professionals assumed to be intrinsically driven by professional or value-based motivations (i.e., stewards rather than agents). Their motivation is based on "making a contribution to their patients and society".

- Managerial rationale in conflict with the professiona rationale: (1) performance management systems are relatively static, which creates tensions with the 


\begin{tabular}{|c|c|c|c|c|c|c|c|}
\hline Authors & Date & Field $^{7}$ & $\begin{array}{l}\text { Context \& } \\
\text { method }\end{array}$ & $\begin{array}{l}\text { Control mechanisms } \\
\text { investigated }\end{array}$ & $\begin{array}{l}\text { Unintended consequences } \\
\text { For actors }\end{array}$ & $\begin{array}{l}\text { For others - } \\
\text { external } \\
\text { stakeholders }\end{array}$ & $\begin{array}{l}\text { Insights that explain how and why unintended } \\
\text { consequences occur }\end{array}$ \\
\hline & & & & & & & $\begin{array}{l}\text { dynamic nature of professional environments; (2) } \\
\text { these systems are driven by management objectives } \\
\text { (transparency, efficiency, costs), while professional } \\
\text { processes are driven by shared standards, cognitive } \\
\text { beliefs and autonomy. Performance management is } \\
\text { perceived to undermine intrinsic motivation, } \\
\text { especially when incentive pay is used and undermines } \\
\text { professional autonomy. } \\
\text { - Unintended consequences generate opportunistic } \\
\text { behaviour, but these may not be perverse (i.e., to } \\
\text { satisfy their own interests). This behaviour may be to } \\
\text { benefit patients or institutions } \\
\text { - Based on the professionalism and cognitive evaluation } \\
\text { theory, unintended consequences can be explained } \\
\text { due to the underlying values that drive medical } \\
\text { professionals (competence and autonomy) } \\
\text { - A third explanation is that the performance } \\
\text { management system inevitably lags behind the } \\
\text { dynamics of the professional process. }\end{array}$ \\
\hline $\begin{array}{l}\text { Kuhlmann, } \\
\text { Bogumil \& } \\
\text { Grohs }\end{array}$ & $(2008)$ & PSM & $\begin{array}{l}\text { Public sector } \\
\text { (Local } \\
\text { governments, } \\
\text { Germany); } \\
\text { Survey and case } \\
\text { studies }\end{array}$ & $\begin{array}{l}\text { Directive: } \\
\text { - Performance } \\
\text { measurement, targets, } \\
\text { evaluation, } \\
\text { benchmarks, } \\
\text { performance-related } \\
\text { rewards (incentive } \\
\text { pay) }\end{array}$ & $\begin{array}{l}\text { - Neglect of the importance of the } \\
\text { relationship between administrators } \\
\text { and politicians } \\
\text { - Time costs } \\
\text { - Risk of corruption and personal } \\
\text { advantages } \\
\text { - Decreased employee morale }\end{array}$ & - No reference & $\begin{array}{l}\text { - The complex reality of political decision making } \\
\text { - A "false theory" about the importance of relationships } \\
\text { and their interwoven nature }\end{array}$ \\
\hline $\mathrm{Li}$ & $(2015)$ & PSM & $\begin{array}{l}\text { Public sector } \\
\text { (Local } \\
\text { government - } \\
\text { Police } \\
\text { department, } \\
\text { China); } \\
\text { Interviews }\end{array}$ & $\begin{array}{l}\text { Directive: } \\
\text { - Performance } \\
\text { measurement and } \\
\text { targets, performance } \\
\text { reviews/evaluation } \\
\text { - Performance-based } \\
\text { rewards (implicit in } \\
\text { text) }\end{array}$ & $\begin{array}{l}\text { Strategic behavioural responses } \\
\text { - Gaming } \\
\text { - Misrepresentation of data by local } \\
\text { officials, } \\
\text { - Manipulation of data reported to } \\
\text { upper-level government officials } \\
\text { - Measure fixation }\end{array}$ & $\begin{array}{l}\text { - Decreased } \\
\text { benefits for the } \\
\text { public/ society } \\
\text { (implicit in } \\
\text { text) }\end{array}$ & - Increase pressure leads to dysfunctions \\
\hline
\end{tabular}




\begin{tabular}{|c|c|c|c|c|c|c|c|}
\hline Authors & Date & Field $^{7}$ & $\begin{array}{l}\text { Context \& } \\
\text { method }\end{array}$ & $\begin{array}{l}\text { Control mechanisms } \\
\text { investigated }\end{array}$ & $\begin{array}{l}\text { Unintended consequences } \\
\text { For actors }\end{array}$ & $\begin{array}{l}\text { For others - } \\
\text { external } \\
\text { stakeholders } \\
\end{array}$ & $\begin{array}{l}\text { Insights that explain how and why unintended } \\
\text { consequences occur }\end{array}$ \\
\hline $\begin{array}{l}\text { Lindsay, } \\
\text { Osborne \& } \\
\text { Bond }\end{array}$ & (2014) & PSM & $\begin{array}{l}\text { Public sector } \\
\text { (Employability } \\
\text { providers, UK); } \\
\text { Case studies } \\
\text { (interviews \& } \\
\text { focus groups) }\end{array}$ & $\begin{array}{l}\text { Directive: } \\
\text { - Planning (strategy } \\
\text { alignment), } \\
\text { performance } \\
\text { measurement, targets, } \\
\text { performance } \\
\text { reporting/reviews, } \\
\text { performance-based } \\
\text { rewards }\end{array}$ & $\begin{array}{l}\text { - Mission drift } \\
\text { - Stifled innovation } \\
\text { - Measure fixation } \\
\text { - Increasing 'contractualism' (less } \\
\text { relational and more standardized } \rightarrow \\
\text { less flexibility) } \\
\text { - Gaming } \\
\text { - Barriers to co-production of public } \\
\text { - services } \\
\text { - Short-termism crowding out long- } \\
\text { term focus }\end{array}$ & - No reference & $\begin{array}{l}\text { - Reasons for unintended consequences associated to } \\
\text { the underlying assumptions of New Public } \\
\text { Management (i.e., agency theory) coupled with the } \\
\text { complexity of governing public services. } \\
\text { - It suggests that for third sector organizations a better } \\
\text { approach would be a relational model of working } \\
\text { based on trust, open information, practice-sharing and } \\
\text { participation of stakeholders based on their expertise, } \\
\text { rather than contractual models, targets and other } \\
\text { market related mechanisms. }\end{array}$ \\
\hline $\begin{array}{l}\text { Lowe \& } \\
\text { Shaw }\end{array}$ & (1968) & GM & $\begin{array}{l}\text { For profit sector } \\
\text { (Sales, US); } \\
\text { Interviews and } \\
\text { archival data }\end{array}$ & $\begin{array}{l}\text { Directive: } \\
\text { - Performance } \\
\text { measurement, targets, } \\
\text { review (budgets), } \\
\text { performance-based } \\
\text { rewards (individual } \\
\text { incentive pay) }\end{array}$ & $\begin{array}{l}\text { - Gaming (slack) } \\
\text { - Misrepresentation of financial } \\
\text { information } \\
\text { - Decision making dysfunctionalities }\end{array}$ & - No reference & $\begin{array}{l}\text { - Design issues (links to pay). People's sense of gain (or } \\
\text { loss) associated with measured performance and } \\
\text { reflected in the various rewards they may or may not } \\
\text { receive may explain slack. } \\
\text { - Influence of company practices and norms } \\
\text { - Managers' insecurity }\end{array}$ \\
\hline $\begin{array}{l}\text { Maas \& Van } \\
\text { Rinsum }\end{array}$ & (2013) & $\mathrm{ACC}$ & $\begin{array}{l}\text { Management } \\
\text { students; } \\
\text { Experiment }\end{array}$ & $\begin{array}{l}\text { Directive: } \\
\text { - Performance-based } \\
\text { rewards (individual } \\
\text { incentive pay and } \\
\text { profit-sharing), } \\
\text { performance reporting }\end{array}$ & - Dishonesty - Misreporting & - No reference & $\begin{array}{l}\text { - Affected by the design of the control system } \\
\text { - Social preferences and social norms }\end{array}$ \\
\hline $\begin{array}{l}\text { Mannion \& } \\
\text { Braithwaite }\end{array}$ & $(2012)^{*}$ & PSM & $\begin{array}{l}\text { Public sector } \\
\text { (Hospitals - } \\
\text { NHS, UK); } \\
\text { Literature } \\
\text { review }\end{array}$ & $\begin{array}{l}\text { Directive: } \\
\text { - Performance } \\
\text { measurement and } \\
\text { targets, performance } \\
\text { reporting/review, } \\
\text { performance-based } \\
\text { rewards }\end{array}$ & $\begin{array}{l}\text { - Poor measurement (measurement } \\
\text { fixation, tunnel vision, myopia, } \\
\text { ossification, anachronism, } \\
\text { quantification privileging) } \\
\text { - Misplaced incentives and sanctions } \\
\text { (complacency, silo-creation, } \\
\text { overcompensation, under- } \\
\text { compensation, insensitivity and } \\
\text { increased inequality) } \\
\text { - Breach of trust (misrepresentation, } \\
\text { gaming, misinterpretation, bullying, }\end{array}$ & $\begin{array}{l}\text { - Decreased } \\
\text { benefits for the } \\
\text { public/society } \\
\text { (implicit in } \\
\text { text) }\end{array}$ & $\begin{array}{l}\text { - Unintended undesirable consequences cannot be } \\
\text { entirely mitigated. They can be minimized if design } \\
\text { issues and the way the measures are used are } \\
\text { improved. }\end{array}$ \\
\hline
\end{tabular}




\begin{tabular}{|c|c|c|c|c|c|c|c|}
\hline Authors & Date & Field $^{7}$ & $\begin{array}{l}\text { Context \& } \\
\text { method }\end{array}$ & $\begin{array}{l}\text { Control mechanisms } \\
\text { investigated }\end{array}$ & $\begin{array}{l}\text { Unintended consequences } \\
\text { For actors }\end{array}$ & $\begin{array}{l}\text { For others - } \\
\text { external } \\
\text { stakeholders } \\
\end{array}$ & $\begin{array}{l}\text { Insights that explain how and why unintended } \\
\text { consequences occur }\end{array}$ \\
\hline & & & & & $\begin{array}{l}\text { erosion of trust and reduced staff } \\
\text { morale) } \\
\text { - Politicisation of performance systems } \\
\text { (political grandstanding and creating } \\
\text { a diversion) }\end{array}$ & & \\
\hline $\begin{array}{l}\text { McCann, } \\
\text { Granter, } \\
\text { Hassard, et } \\
\text { al. }\end{array}$ & (2015) & $\mathrm{HR}$ & $\begin{array}{l}\text { Public sector } \\
\text { (Hospitals - } \\
\text { NHS, UK); } \\
\text { ethnographic } \\
\text { study }\end{array}$ & $\begin{array}{l}\text { Directive: } \\
\text { - Performance } \\
\text { measures and targets }\end{array}$ & $\begin{array}{l}\text { - Targets culture } \\
\text { - Workforce morale and dysfunctional } \\
\text { employee relations } \\
\text { - Selective prioritization } \\
\text { - Gaming } \\
\text { - Ignoring } \\
\text { - Working around targets }\end{array}$ & $\begin{array}{l}\text { - Negative } \\
\text { outcomes for } \\
\text { patients' care }\end{array}$ & $\begin{array}{l}\text { - Conflicting logics of efficiency and integrity of care } \\
\text { generate tensions on an everyday basis. The } \\
\text { inclination of staff is to prioritise integrity of care but } \\
\text { this can be problematic due to the pressures of } \\
\text { accountability. Staff responds to the tensions as } \\
\text { "street-level bureaucrats" looking for the best } \\
\text { outcome for patients, which can lead to unintended } \\
\text { consequences (from the point of view of the } \\
\text { performance management system, but not from the } \\
\text { point of view of patients) } \\
\text { - Over time, tensions may lead to a dysfunctional work } \\
\text { culture focused on 'making the numbers' affecting } \\
\text { intrinsic motivations and morale. }\end{array}$ \\
\hline Merchant & (1990) & $\mathrm{ACC}$ & $\begin{array}{l}\text { For profit (Large } \\
\text { Fortune } 300 \text {, } \\
\text { US); Interviews } \\
\text { and survey }\end{array}$ & $\begin{array}{l}\text { Directive: } \\
\text { - Performance } \\
\text { measures and targets } \\
\text { (budgets) }\end{array}$ & $\begin{array}{l}\text { - Manipulation } \\
\text { - Myopia (short-term orientation) } \\
\text { - Gaming } \\
\text { - Discouragement of new ideas } \\
\text { - Improvements in the short-term } \\
\text { financial results while harming the } \\
\text { company's long-term interests }\end{array}$ & - No reference & $\begin{array}{l}\text { - Increase pressure to meet targets leads to dysfunctions } \\
\text { - Managers operating in relatively uncertain } \\
\text { environments were significantly more likely to react } \\
\text { to budget pressure by gaming the system }\end{array}$ \\
\hline Murphy & (2004) & GM & $\begin{array}{l}\text { For profit - } \\
\text { various } \\
\text { industries (Sales, } \\
\text { UK); Survey }\end{array}$ & $\begin{array}{l}\text { Directive: } \\
\text { - Performance } \\
\text { measurement and } \\
\text { targets }\end{array}$ & $\begin{array}{l}\text { "Problematic behaviours" due to short- } \\
\text { term targets } \\
\text { - Gaming (extra purchases, } \\
\text { overemphasis on target products, } \\
\text { increased credit risks) } \\
\text { - Neglect of work aspects that are not } \\
\text { related to short-term targets } \\
\text { - Reduce helping and sharing } \\
\text { information } \\
\text { - Exaggerate claims of targeted } \\
\text { offerings }\end{array}$ & $\begin{array}{l}\text { - Implicit } \\
\text { reference to } \\
\text { negative } \\
\text { consequences } \\
\text { for society due } \\
\text { to unethical } \\
\text { behaviours }\end{array}$ & $\begin{array}{l}\text { - Increase pressure leads to dysfunctions } \\
\text { - They are less likely to occur in organizations with } \\
\text { safeguards in place (e.g., corporate reputation, codes, } \\
\text { reinforcing mechanisms encouraging ethical } \\
\text { behaviour) and high commitment/trust environments } \\
\text { - Some people are more (or less) prone to problematic } \\
\text { behaviours (people with high-status aspiration and } \\
\text { competitiveness may require more controls; highly } \\
\text { educated people, people with high affective } \\
\text { commitment, and those with close relationships to } \\
\text { supervisor may require less control) }\end{array}$ \\
\hline
\end{tabular}




\begin{tabular}{|c|c|c|c|c|c|c|c|}
\hline Authors & Date & Field $^{7}$ & $\begin{array}{l}\text { Context \& } \\
\text { method }\end{array}$ & $\begin{array}{l}\text { Control mechanisms } \\
\text { investigated }\end{array}$ & $\begin{array}{l}\text { Unintended consequences } \\
\text { For actors }\end{array}$ & $\begin{array}{l}\text { For others - } \\
\text { external } \\
\text { stakeholders } \\
\end{array}$ & $\begin{array}{l}\text { Insights that explain how and why unintended } \\
\text { consequences occur }\end{array}$ \\
\hline Otley & (1978) & $\mathrm{ACC}$ & $\begin{array}{l}\text { For profit } \\
\text { (Manufacturing } \\
\text { subunits, UK) } \\
\text { Survey and Case } \\
\text { study }\end{array}$ & $\begin{array}{l}\text { Directive: } \\
\text { - Performance } \\
\text { measurement, targets, } \\
\text { evaluation (budgets) }\end{array}$ & $\begin{array}{l}\text { - Gaming } \\
\text { - Misrepresentation }\end{array}$ & - No reference & $\begin{array}{l}\text { - Distortion of information can occur even when the } \\
\text { system is technically adequate. } \\
\text { - The way in which accounting information is used is } \\
\text { conditioned partly on managers' managerial } \\
\text { philosophy (key shared assumptions) and it may vary } \\
\text { from unit to unit according to the toughness of its } \\
\text { operating environment and its size and profitability. } \\
\text { - The way in which the system is used by different } \\
\text { manager has a marked effect on the accuracy } \\
\text { of budget estimates. } \\
\text { - There was collusion between mangers to provide } \\
\text { biased information to higher levels, but to manage } \\
\text { locally recognizing these inaccuracies. }\end{array}$ \\
\hline $\begin{array}{l}\text { Rankin, } \\
\text { Schwartz \& } \\
\text { Young }\end{array}$ & (2008) & $\mathrm{ACC}$ & $\begin{array}{l}\text { Management } \\
\text { students; } \\
\text { Experiment }\end{array}$ & $\begin{array}{l}\text { Directive: } \\
\text { - Performance } \\
\text { measurement, targets, } \\
\text { reporting (budgets) }\end{array}$ & $\begin{array}{l}\text { - Dishonesty (misrepresentation of } \\
\text { financial information - depending on } \\
\text { the design of control system) }\end{array}$ & - No reference & $\begin{array}{l}\text { - Explanations based on agency theory assumptions: "in } \\
\text { the absence of truth-inducing contracts, subordinates } \\
\text { will misrepresent their private information to serve } \\
\text { their own interests, regardless of the effect on the } \\
\text { firm"; however, their level of dishonesty depends on } \\
\text { budget design decisions. } \\
\text { - One of these decisions refers to authority over } \\
\text { budgets. When subordinates have final authority over } \\
\text { budgets their concerns for fairness and honesty are } \\
\text { higher, when superiors have final authority there is no } \\
\text { significant difference in honesty levels. }\end{array}$ \\
\hline
\end{tabular}




\begin{tabular}{|c|c|c|c|c|c|c|c|}
\hline \multirow[t]{2}{*}{ Authors } & \multirow[t]{2}{*}{ Date } & \multirow{2}{*}{ Field $^{7}$} & \multirow{2}{*}{$\begin{array}{l}\text { Context \& } \\
\text { method }\end{array}$} & \multicolumn{3}{|c|}{ Control mechanisms Unintended consequences } & \multirow{2}{*}{$\begin{array}{l}\text { Insights that explain how and why unintended } \\
\text { consequences occur }\end{array}$} \\
\hline & & & & investigated & For actors & $\begin{array}{l}\text { For others - } \\
\text { external } \\
\text { stakeholders }\end{array}$ & \\
\hline Ridgway & $(1956)$ & GM & $\begin{array}{l}\text { Various sectors, } \\
\text { industries (US, } \\
\text { Russia); } \\
\text { Conceptual/ } \\
\text { Literature } \\
\text { review }\end{array}$ & $\begin{array}{l}\text { Directive: } \\
\text { - Performance } \\
\text { measurement and } \\
\text { targets }\end{array}$ & $\begin{array}{l}\text { - Measure fixation } \\
\text { - Work distortion (gaming) } \\
\text { - Neglect of work aspects that can't be } \\
\text { measured } \\
\text { - "Storming" at the end of target period } \\
\text { - Distrust (both on data due to } \\
\text { misrepresentation and on people) } \\
\text { - Blaming } \\
\text { - Wasted effort } \\
\text { - Rejection of complexity that may } \\
\text { - Reduced moned measured results } \\
\text { - Ratchet effect } \\
\text { - Adverse influence on overall goal } \\
\text { accomplishment of the organization }\end{array}$ & $\begin{array}{l}\text { No reference } \\
\text { d }\end{array}$ & $\begin{array}{l}\text { - Motivational and behavioural aspects affected by the } \\
\text { use of performance measures }\end{array}$ \\
\hline $\begin{array}{l}\text { Salterio \& } \\
\text { Webb }\end{array}$ & $(2006)$ & $\mathrm{ACC}$ & $\begin{array}{l}\text { For profit and } \\
\text { non-for-profit } \\
\text { sectors; } \\
\text { Literature } \\
\text { review }\end{array}$ & $\begin{array}{l}\text { Directive: } \\
\text { - Performance } \\
\text { measurement, targets, } \\
\text { review (budget), } \\
\text { performance-based } \\
\text { rewards (individual } \\
\text { incentive pay) }\end{array}$ & $\begin{array}{l}\text { - Lying/ dishonesty (misrepresentation } \\
\text { of information) }\end{array}$ & - No reference & $\begin{array}{l}\text { - Assumptions about people's behaviour related to } \\
\text { unintended consequences }\end{array}$ \\
\hline $\begin{array}{l}\text { Schiff \& } \\
\text { Lewin }\end{array}$ & $(1970)$ & $\mathrm{ACC}$ & $\begin{array}{l}\text { Various } \\
\text { contexts; } \\
\text { Conceptual }\end{array}$ & $\begin{array}{l}\text { Directive: } \\
\text { - Performance } \\
\text { measurement and } \\
\text { targets (budgets) }\end{array}$ & - Gaming (Slack) & - No reference & - Managers satisfaction of personal interests \\
\hline $\begin{array}{l}\text { Schwepker } \\
\& \text { Good }\end{array}$ & $(2012)$ & GM & $\begin{array}{l}\text { For profit sector, } \\
\text { (Business-to- } \\
\text { business } \\
\text { salespeople, } \\
\text { US); Survey }\end{array}$ & $\begin{array}{l}\text { Directive: } \\
\text { - Performance } \\
\text { measures and targets } \\
\text { (focus on perceived } \\
\text { difficulty of target } \\
\text { achievement) } \\
\text { ** The research does } \\
\text { not pay attention to } \\
\text { planning, review or }\end{array}$ & $\begin{array}{l}\text { - Decreased trust in the organization } \\
\text { - Decreased customer-oriented selling } \\
\text { - Decreased effectiveness of sales- } \\
\text { oriented behaviour }\end{array}$ & - No reference & $\begin{array}{l}\text { - Design issues (increased target difficulty leads to } \\
\text { greater unintended consequences) }\end{array}$ \\
\hline
\end{tabular}




\begin{tabular}{|c|c|c|c|c|c|c|c|}
\hline Authors & Date & Field $^{7}$ & $\begin{array}{l}\text { Context \& } \\
\text { method }\end{array}$ & $\begin{array}{l}\text { Control mechanisms } \\
\text { investigated }\end{array}$ & $\begin{array}{l}\text { Unintended consequences } \\
\text { For actors }\end{array}$ & $\begin{array}{l}\text { For others - } \\
\text { external } \\
\text { stakeholders }\end{array}$ & $\begin{array}{l}\text { Insights that explain how and why unintended } \\
\text { consequences occur }\end{array}$ \\
\hline & & & & $\begin{array}{l}\text { reward mechanisms but } \\
\text { it assumes they exists. }\end{array}$ & & & \\
\hline $\begin{array}{l}\text { Segal \& } \\
\text { Lehrer }\end{array}$ & $(2012)^{*}$ & GM & $\begin{array}{l}\text { Non-for-profit } \\
\text { (Education, } \\
\text { Canada); } \\
\text { Literature } \\
\text { review and case } \\
\text { study }\end{array}$ & $\begin{array}{l}\text { Directive: } \\
\text { - Performance } \\
\text { measurement, targets, } \\
\text { review } \\
\text { Enabling: } \\
\text { - Social controls, peer } \\
\text { monitoring, } \\
\text { partnership culture, } \\
\text { self-monitoring \& } \\
\text { reflective thinking, } \\
\text { share leadership }\end{array}$ & $\begin{array}{l}\text { Directive: } \\
\text { - Mistrust } \\
\text { - Deviance } \\
\text { - Alienation } \\
\text { Enabling: } \\
\text { - Minor corruption }\end{array}$ & $\begin{array}{l}\text { Directive: } \\
\text { - Low quality } \\
\text { education } \\
\text { - Serious } \\
\text { corruption } \\
\text { Enabling } \\
\text { - No reference }\end{array}$ & $\begin{array}{l}\text { - Assumptions about people's behaviour (self-fulfilling } \\
\text { prophecy) } \\
\text { - Increased pressure to perform } \\
\text { - Organizational complexity }\end{array}$ \\
\hline Smith & $(1995 a)^{*}$ & PSM & $\begin{array}{l}\text { For profit and } \\
\text { non-for-profit } \\
\text { sectors (UK); } \\
\text { Literature } \\
\text { review }\end{array}$ & $\begin{array}{l}\text { Directive: } \\
\text { - Performance } \\
\text { planning, } \\
\text { performance } \\
\text { measures, targets, } \\
\text { review, performance } \\
\text { related rewards } \\
\text { (monetary and non- } \\
\text { monetary) }\end{array}$ & $\begin{array}{l}\text { - Tunnel vision } \\
\text { - Sub-optimization } \\
\text { - Myopia } \\
\text { - Measure fixation } \\
\text { - Misrepresentation } \\
\text { - Misinterpretation } \\
\text { - Gaming } \\
\text { - Ossification }\end{array}$ & $\begin{array}{l}\text { - Decreased } \\
\text { benefits for the } \\
\text { public/society } \\
\text { (implicit in } \\
\text { text) }\end{array}$ & $\begin{array}{l}\text { - Lack of congruence between organizational objectives } \\
\text { and measurement system } \\
\text { - Inability to measure complex phenomena with } \\
\text { precision and accuracy } \\
\text { - Inability to respond to changing circumstances }\end{array}$ \\
\hline Tan \& Rae & (2009) & PSM & $\begin{array}{l}\text { Various } \\
\text { contexts, but } \\
\text { most research } \\
\text { selected comes } \\
\text { from public } \\
\text { sector; Literature } \\
\text { review }\end{array}$ & $\begin{array}{l}\text { Directive controls: } \\
\text { - Performance } \\
\text { measurement, targets, } \\
\text { evaluation, } \\
\text { performance-based } \\
\text { rewards (individual } \\
\text { incentive pay) }\end{array}$ & $\begin{array}{l}\text { - Commodifying services } \\
\text { - De-professionalization of public } \\
\text { sector workers } \\
\text { - Social relationships transformation } \\
\text { (emphasis on measured aspects) } \\
\text { - Values become less important than } \\
\text { measures } \\
\text { - Time costs }\end{array}$ & $\begin{array}{l}\text { - Environmental } \\
\text { consequences } \\
\text { due to } \\
\text { measures in } \\
\text { airports }\end{array}$ & $\begin{array}{l}\text { - Increased pressure } \\
\text { - High complexity (e.g., airports, health care } \\
\text { organizations) } 1\end{array}$ \\
\hline
\end{tabular}


Table 3. Summary of literature review insights

Literature
Performance management systems
Definition
Set of control mechanisms (planning,
measurement, targets, review, performance
related rewards) used to facilitate the
delivery of organizational goals by
influencing people's behaviours and
performance

\section{Shared assumptions}

- Interrelated controls

- In constant evolution

- Formal and informal

- Based on predictive mental models

\section{Theories}

- Contingency theory of accounting (Otley, 1980, 2016)

- 'Universal approach' to the design and use of controls unlikely to be effective.

- Controls are to be tailored to fit the organization's specific circumstances to provide their intended results.

- Agency theory (Eisenhardt, 1989; Jensen and Meckling, 1976)

- Assumptions: agents (employees) $=$ 'Economic man' (self-serving or opportunistic, effort-averse, riskaverse, extrinsic drive/motivation); the ultimate objective is organizational goals maximization

- Problems that need addressing: interests/goals alignment; uncertainty (information asymmetry)

- Proposed solution - adoption of 'directive' control mechanisms: monitoring (explicit goals, measures, targets, evaluation) and incentives

- Stewardship theory (Davis et al., 1997b; Hernandez, 2012)

- Assumptions: stewards (employees) $=$ shared responsibilities and long-term goals, intrinsic motivation

- Problems that need addressing: uncertainty (environmental) and maintenance of alignment (associated to intrinsic drives/motivation)

- Proposed solution - adoption of 'enabling' mechanisms: fostering high-trust environments through share leadership, collective responsibility, intrinsic rewards, continuous development.

\section{Shared assumptions}

- There is an intention from the point of view of the designer of a performance management system

- Unintended consequences (desirable and undesirable) are inevitable.

- Undesirable consequences can turn to be perverse (more harm than good)

- Undesirable consequences can be minimized, never eliminated

- It is important to theorize undesirable consequences to minimize them

\section{Theories}

- Merton (1936) explains unintended consequences as resulting from the interplay of action and situation. The lack of anticipation might be due five limiting factors: lack of knowledge, error, acute concern for short-term results, values (or ideology), self-fulfilling prophecy.

These factors are not mutually exclusive (they can reinforce each other).

- Elias $(1997,1998)$ explains unintended consequences
SYSTEMATIC

\section{Literature}

Unintended consequences of performance management systems

- Organisations relying on directive performance management systems (i.e., agency theory related) in highly uncertain contexts are likely to experience more undesirable unintended consequences not just for the actors but also for their stakeholders

What are the most salient unintended undesirable consequences?

- Gaming (81\% of selected literature)

- Information manipulation (74\%)

- Selective attention (55\%)

- Illusion of control (24\%)

- Alter social relationships (81\%)

Other:

- Administrative overload and managerial time costs (14\%); 'ossification' (14\%); deprofessionalization (10\%); decreased well-being and morale (10\%); stifled innovation (5\%); unfairness and inequality $(5 \%)$.

How and why do unintended undesirable consequences occur?

- High pressure

- Design and use issues

- Complexity and uncertainty

- Underlying assumptions (false assumptions about people, importance of relationships and context complexity) 
Figure 1. Conceptual framework of the unintended consequences of performance management systems (PMS)

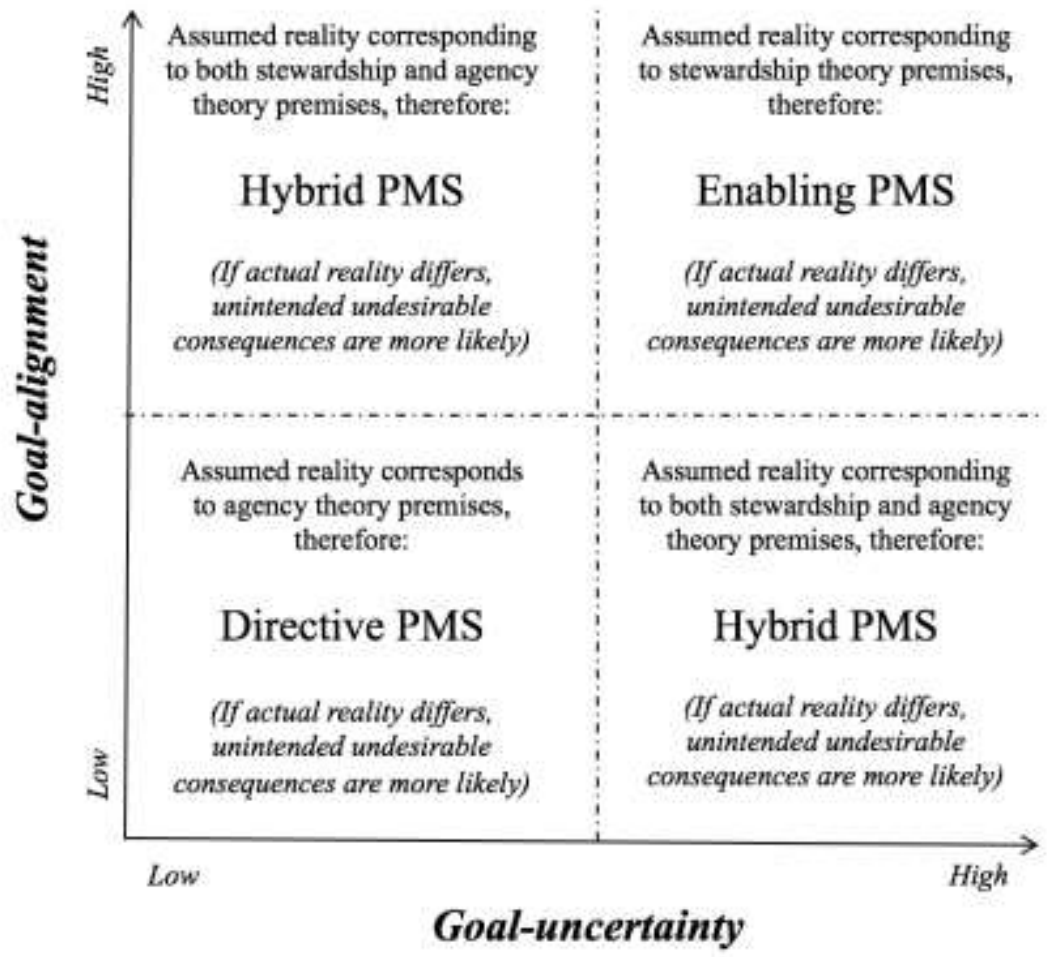

